\title{
Selective lignin and polysaccharide removal in natural fungal decay of wood as evidenced by in situ structural analyses
}

Angel T. Martínez, ${ }^{1 *}$ Jorge Rencoret, ${ }^{2 \dagger}$ Lidia Nieto, ${ }^{1}$ Jesús Jiménez-Barbero, ${ }^{1}$ Ana Gutiérrez ${ }^{2}$ and José C. del Río**

${ }^{1}$ Centro de Investigaciones Biológicas, CSIC, Ramiro de Maeztu 9, E-28040 Madrid, Spain.

2Instituto de Recursos Naturales y Agrobiología de Sevilla, CSIC, P.O. Box 1052, E-41080-Seville, Spain.

\section{Summary}

Selective modification/degradation of the main plant polymers (cellulose, hemicelluloses and lignin) was investigated in a hardwood after white and brown-rot fungal decay under environmental conditions. The chemical changes produced in the plant cell wall were analysed in situ, by nuclear magnetic resonance (NMR) at the gel state, and analytical pyrolysis. Twodimensional (2D) NMR of the white-rotted wood showed only cellulose and (deacetylated) hemicellulose, and the complete removal of lignin. On the other hand, the brown-rotted wood showed the nearly complete absence of polysaccharides, while the main features of lignin structure, as revealed by 2D-NMR, could be observed. These included well-resolved aromatic and side-chain cross-signals, although the intensity of the latter signals was lowered indicating a reduction in the number of side-chain linkages $\left(\beta-0-4^{\prime}\right.$ and $\left.\beta-\beta^{\prime}\right)$ per aromatic unit (their relative abundances remaining unchanged). These results contrast with a recent study concluding that the aromatic polymer after brown-rot decay is not longer recognized as lignin. Some oxidative alteration of lignin during brown-rot decay was evidenced and, more interesting, several compounds with 3-methoxycatechol skeleton were released upon pyrolysis. Lignin demethylation is consistent with recent brown-rot transcriptomic/ secretomic studies showing overexpression of methanol oxidase, which could use lignin-derived methanol

Received 16 April, 2010; accepted 16 June, 2010. For correspondence. *E-mail atmartinez@cib.csic.es; Tel. (+34) 918373112 (ext 4407); Fax (+34) 915360432; or **E-mail delrio@ irnase.csic.es; Tel. (+34) 954624711 (ext 119); Fax (+34) 954624002. 'Present address: Great Lakes Bioenergy Research Center, University of WisconsinMadison, WI, USA. to generate the peroxide required for cellulose depolymerization via Fenton chemistry.

\section{Introduction}

The major constituents of wood are cellulose, hemicelluloses and lignin (Higuchi, 1997). The latter is a recalcitrant aromatic polymer, which protects the plant structural polysaccharides against microbial attack, and also plays other roles in wood tissues (Gellerstedt and Henriksson, 2008). Wood-rotting fungi play a central ecological role in forest ecosystems enabling the cycling of the carbon fixed by plant photosynthesis, since other microorganisms are not able to remove or circumvent the lignin barrier (Martínez et al., 2005). In a similar way, the access to plant polysaccharides represents a central issue for the industrial use of plant biomass (e.g. in paper pulp manufacture or bioethanol production).

White-rot fungi are the only organisms being able to degrade (mineralize) lignin in wood, thus opening up the plant cell wall. The white-rotted wood often presents a whitish colour, hence the name 'white-rot fungi'. In most cases, lignin removal by white-rot fungi parallels some degradation of polysaccharides, mainly hemicelluloses, in the so-called simultaneous degradation pattern (Otjen and Blanchette, 1986). However, a few white-rot species are able to remove lignin without causing a significant loss of polysaccharides, in a selective degradation pattern that has the highest biotechnological interest. On the other hand, brown-rot fungi have developed a different decay strategy being able to degrade most of the cellulose and hemicelluloses leaving the lignin polymer. The brownrotted wood becomes therefore enriched in lignin and presents a dark reddish-brown to golden colour, and thus its name.

Due to the above characteristics, both white-rot (Watanabe, 2007) and brown-rot basidiomycetes (Schilling et al., 2009) are attracting considerable attention as models for two different strategies of wood attack. These biotechnological models are of interest in lignocellulose biorefineries, for the sustainable production of chemicals, materials and fuels from renewable plant resources (Ragauskas et al., 2006). Interestingly, the model whiterot fungus Phanerochaete chrysosporium was the first 
basidiomycete whose genome was sequenced (Martínez et al., 2004), and the Postia placenta genome has been recently sequenced as a model brown-rot fungus (Martínez et al., 2009a). The mechanism of lignin removal by white-rot basidiomycetes has been extensively investigated during last years, mainly with the aim of developing biotechnological applications for the pulp and paper industry (Martínez et al., 2009b). It has been found to be constituted by unique high redox-potential peroxidases and $\mathrm{H}_{2} \mathrm{O}_{2}$-generating oxidases, among other enzymes (Ruiz-Dueñas and Martínez, 2009). In contrast, the mechanism of wood attack by brown-rot fungi is more poorly understood. In particular, the way used by these fungi to circumvent the lignin barrier, and be able to degrade cellulose is still under investigation (Baldrian and Valaskova, 2008). Such a mechanism is of biotechnological interest when simple sugars are to be obtained from wood, e.g. for fermentation and production of ethanol or other chemical compounds.

Elucidating the mechanisms of biological degradation or modification of lignin is a difficult task due to its complex macromolecular structure (a branched polymer including different units and inter-unit bonds) and intimate association to cell-wall polysaccharides (Gellerstedt and Henriksson, 2008). For many years, simple model compounds were used to establish the main reactions caused by lignin-modifying organisms (Kishimoto, 2009). However, some modern analytical techniques, such as twodimensional (2D) or three-dimensional (3D) nuclear magnetic resonance (NMR), provided new tools for the analysis of complex macromolecules, like lignin. In fact, several new lignin substructures were for the first time detected using 2D-NMR (Karhunen et al., 1995; Zhang et al., 2006). Moreover, studies with ionic liquids and other strong solvents have recently shown the possibility to analyse plant polymers in situ (Lu and Ralph, 2003; Kilpelainen et al., 2007; Yelle et al., 2008a), overcoming the isolation problem that, in the case of lignin, always results in low recovery and chemical modifications (Fujimoto et al., 2005).

In the present work, previously characterized samples of Eucryphia cordifolia wood extensively degraded by the white-rot fungus Ganoderma australe and by an unidentified brown-rot basidiomycete under environmental conditions in the Austral rainforest (Martínez et al., 1991) were analysed using modern techniques. For the NMR analyses, the chemical modifications were analysed in situ by heteronuclear single quantum (HSQC) experiments on the whole wood sample using a method that consists in swelling finely ground samples in deuterated dimethylsulfoxide (DMSO- $d_{6}$ ) and forming a gel in the NMR tube (Kim et al., 2008; Rencoret et al., 2009). Pyrolysis coupled to gas chromatography/mass spectrometry (Py-GC/MS) is a convenient tool for the rapid analysis of lignin, and has been already used to characterize different patterns of wood decay by fungi (del Río et al., 2001; 2002). In this work, pyrolysis of the whole wood was performed both in the absence and in the presence of tetrabutylammonium hydroxide $(\mathrm{Py} / \mathrm{TBAH})$. The latter results in alkaline degradation (thermochemolysis) and simultaneous butylation (of acid and phenolic groups) facilitating products analysis by GC/MS (del Río et al., 1996).

The aim of the study is to provide new information on the wood-rotting processes by the use of the above analytical techniques, with special emphasis of the fungal alterations of the recalcitrant lignin polymer. Although 2D-NMR of wood gels after in vitro brown-rot fungal decay has been reported (Yelle et al., 2008b), this is the first time that this analytical approach is applied on wood decayed under environmental conditions in the field. The present study also tries to clarified some discrepancies with the generally accepted wood-rot patterns, raised during the in vitro study mentioned above, which claimed that the aromatic polymer remaining after brown rot cannot be longer recognized as lignin. Finally, the changes observed in the composition and structure of the decayed wood polymers are discussed taking into account the biochemical information available, as well as the data provided by recent genomic, transcriptomic and secretomic studies on woodrotting basidiomycetes.

\section{Results and discussion}

\section{General characteristics of the rotted wood samples}

White- and brown-rot decay of E. cordifolia wood were revealed by the characteristic visual aspect of wood (see Fig. S1a and b), together with microscopic examination (Fig. S1c and d), and chemical analyses. The latter revealed a selective removal of lignin (94\% of the initial amount) and conservation of cellulose (only $24 \%$ of the total glucose, including hemicellulose glucans, was removed) by the white-rot fungus; in contrast with the selective removal of cellulose ( $92 \%$ of the initial glucan) and conservation of lignin (only $1 \%$ of its initial amount was removed) after the brown-rot decay (xylan was largely removed, 96-99\%, in both cases). Interestingly, the weight losses caused by the two fungi on the $E$. cordifolia wood (estimated from the decrease of its bulk density) were very similar (61-62\%) facilitating the present comparison of the two decay patterns.

\section{Divergent white- and brown-rot patterns as shown by wood NMR at the gel state}

Figure 1a-c shows the HSQC 2D-NMR spectra of the whole sound, white-rotted and brown-rotted woods 

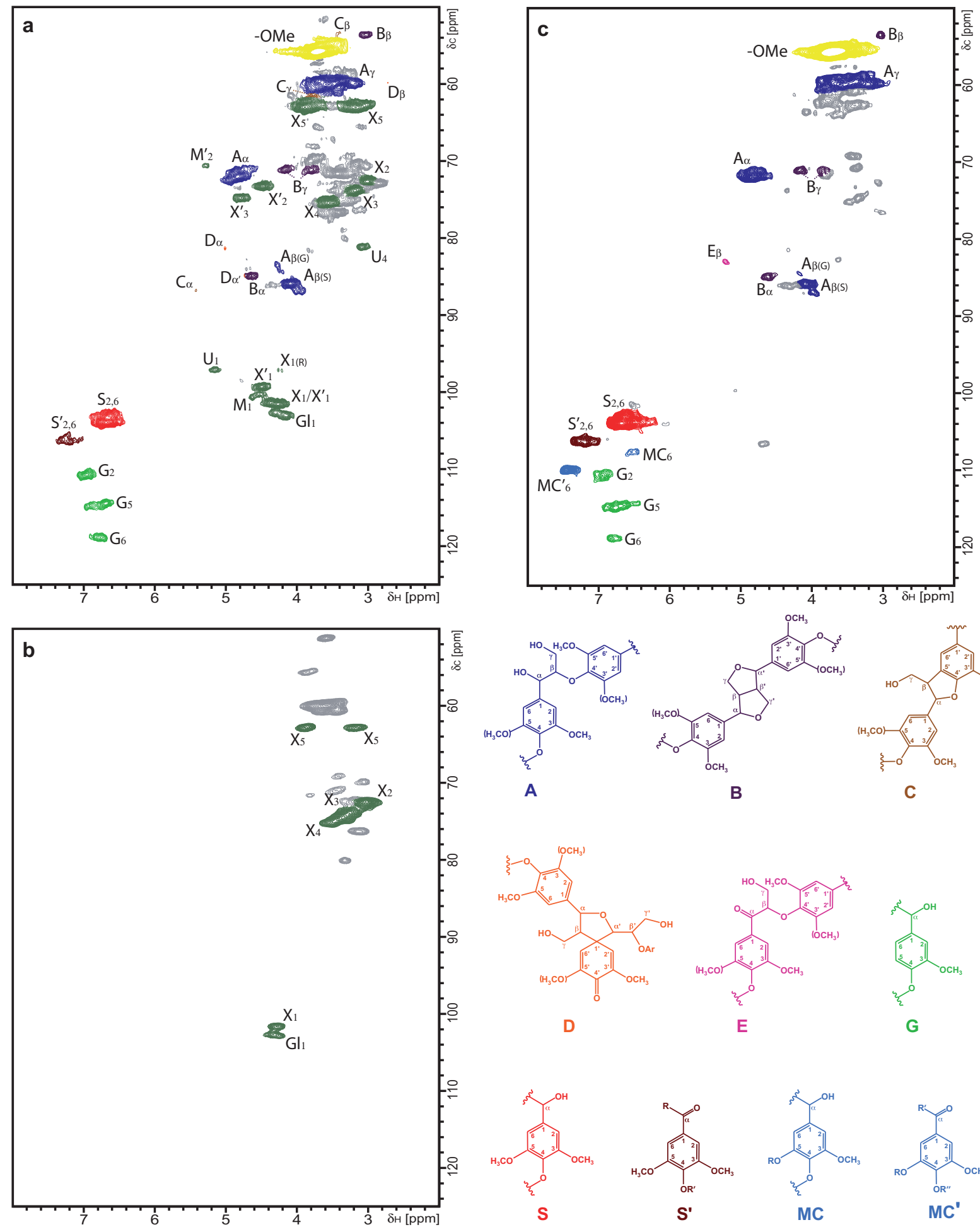

A<smiles>CCOc1cc(C2OCC3C(c4cc(OC)c(OC)c(OC)c4)OCC23)cc(OC)c1OC</smiles>

B

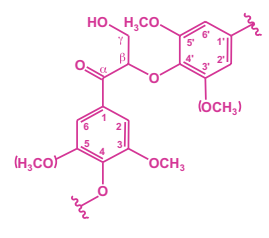

E

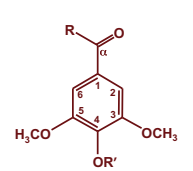

S'

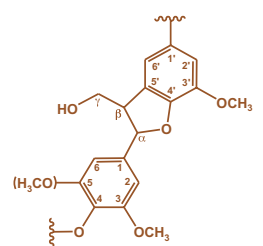

C<smiles>CCC(C)Oc1ccc(C(C)C)cc1O</smiles>

G

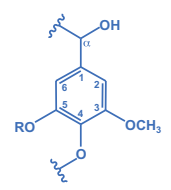

MC

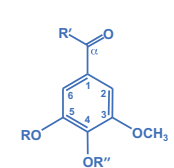

MC'

Fig. 1. Two-dimensional (2D) NMR spectra (HSQC experiments) at the gel state of: (a) sound E. cordifolia wood; (b) E. cordifolia wood after selective white-rot fungal decay under environmental conditions (by G. australe); and (c) E. cordifolia wood after selective brown-rot fungal decay under environmental conditions. The lignin structures identified are also shown: (A) $\beta-O-4^{\prime}$ substructure; (B) resinol substructure; (C) phenylcoumaran substructure; (D) spirodienone substructure; $(E) C_{\alpha}$-oxidized substructure A; $(G)$ guaiacyl unit; (S) syringyl unit; ( $S^{\prime}$ )

$\mathrm{C}_{\alpha}$-oxidized $\mathrm{S}$ unit (R, lignin or $\mathrm{OH} ; \mathrm{R}^{\prime}, \mathrm{H}$ or lignin); (MC) 5-hydroxyguaiacyl $(\mathrm{R}, \mathrm{H})$ or 5-aryl-ether-guaiacyl unit (R, lignin aromatic ring); (MC') $\mathrm{C}_{\alpha}$-oxidized MC unit ( $\mathrm{R}^{\prime}$, lignin or $\mathrm{OH} ; \mathrm{R}^{\prime \prime}, \mathrm{H}$ or lignin). See Table 1 for signal assignment. 
Table 1. Assignment of lignin and polysaccharide ${ }^{13} \mathrm{C}-{ }^{-1} \mathrm{H}$ correlation signals in the HSQC spectra shown in Fig. 1.

\begin{tabular}{|c|c|c|}
\hline Labels & $\delta_{\mathrm{C}} / \delta_{\mathrm{H}}(\mathrm{ppm})$ & Assignment \\
\hline \multicolumn{3}{|c|}{ Lignin cross-signals: } \\
\hline $\mathrm{B}_{\beta}$ & $53.7 / 3.12$ & $\mathrm{C}_{\beta}-\mathrm{H}_{\beta}$ in $\beta-\beta^{\prime}$ (resinol) substructures \\
\hline $\mathrm{C}_{\beta}$ & $53.7 / 3.44$ & $\mathrm{C}_{\beta}-\mathrm{H}_{\beta}$ in $\beta-5^{\prime}$ (phenylcoumaran) substructures \\
\hline$A_{\gamma}$ & 60.0/3.38-3.71 & $\mathrm{C}_{\gamma}-\mathrm{H}_{\gamma}$ in $\beta-O-4^{\prime}$ substructures and others \\
\hline$D_{\beta}$ & $60.3 / 2.75$ & $\mathrm{C}_{\beta}-\mathrm{H}_{\beta}$ in $\beta-1^{\prime}$ (spirodienone) substructures \\
\hline $\mathrm{B}_{\gamma}$ & $71.7 / 3.81$ and 4.17 & $\mathrm{C}_{\gamma}-\mathrm{H}_{\gamma}$ in $\beta-\beta^{\prime}$ (resinol) substructures \\
\hline$A_{\alpha}$ & $72.3 / 4.86$ & $\mathrm{C}_{\alpha}-\mathrm{H}_{\alpha}$ in $\beta-O-4^{\prime}$ substructures \\
\hline $\mathrm{D}_{\alpha}$ & $81.7 / 5.09$ & $\mathrm{C}_{\alpha}-\mathrm{H}_{\alpha}$ in $\beta-1^{\prime}$ (spirodienone) substructures \\
\hline$E_{\beta}$ & $83.6 / 5.21$ & $\mathrm{C}_{\beta}-\mathrm{H}_{\beta}$ in $\mathrm{C}_{\alpha}$-oxidized $\beta-O-4^{\prime}$ substructures \\
\hline$A_{\beta(G)}$ & $84.1 / 4.28$ & $\mathrm{C}_{\beta}-\mathrm{H}_{\beta}$ in $\beta-O-4^{\prime}$ substructures linked to a guaiacyl unit \\
\hline $\mathrm{B}_{\alpha}$ & $85.4 / 4.64$ & $\mathrm{C}_{\alpha}-\mathrm{H}_{\alpha}$ in $\beta-\beta^{\prime}$ (resinol) substructures \\
\hline$A_{B(S)}$ & $86.5 / 4.10$ & $\mathrm{C}_{\beta}-\mathrm{H}_{\beta}$ in $\beta-O-4^{\prime}$ substructures linked to a syringyl unit \\
\hline $\mathrm{D}_{\alpha}^{\prime}$ & 86.6/4.39 & $\mathrm{C}_{\alpha}^{\prime}-\mathrm{H}_{\alpha}^{\prime}$ in $\beta-1^{\prime}$ (spirodienone) substructures \\
\hline $\mathrm{C}_{\alpha}$ & $87.7 / 5.45$ & $\mathrm{C}_{\alpha}-\mathrm{H}_{\alpha}$ in $\beta-5^{\prime}$ (phenylcoumaran) substructures \\
\hline $\mathrm{S}_{2,6}$ & $103.9 / 6.68$ & $\mathrm{C}_{2}-\mathrm{H}_{2}$ and $\mathrm{C}_{6}-\mathrm{H}_{6}$ in syringyl units \\
\hline$S_{2,6}^{\prime}$ & $106.3 / 7.36$ and 7.21 & $\mathrm{C}_{2}-\mathrm{H}_{2}$ and $\mathrm{C}_{6}-\mathrm{H}_{6}$ in $\mathrm{C}_{\alpha}$-oxidized syringyl units \\
\hline $\mathrm{MC}_{6}$ & $107.8 / 6.58$ & $\mathrm{C}_{6}-\mathrm{H}_{6}$ in 5-hydroxy/5-aryl-ether guaiacyl units (t) \\
\hline $\mathrm{MC}_{6}^{\prime}$ & $110.4 / 7.33$ & $\mathrm{C}_{6}-\mathrm{H}_{6}$ in $\mathrm{C}_{\alpha}$-oxidized 5-hydroxy/5-aryl-ether guaiacyl units ( $\mathrm{t}$ ) \\
\hline $\mathrm{G}_{2}$ & $110.8 / 6.96$ & $\mathrm{C}_{2}-\mathrm{H}_{2}$ in guaiacyl units \\
\hline $\mathrm{G}_{5}$ & $114.9 / 6.71$ and 6.94 & $\mathrm{C}_{5}-\mathrm{H}_{5}$ in guaiacyl units \\
\hline $\mathrm{G}_{6}$ & $118.9 / 6.82$ & $\mathrm{C}_{6}-\mathrm{H}_{6}$ in guaiacyl units \\
\hline \multicolumn{3}{|c|}{ Polysaccharide signals: } \\
\hline$X_{5}$ & $62.8 / 3.19$ and 3.87 & $\mathrm{C}_{5}-\mathrm{H}_{5}$ in $\beta$-D-xylopyranoside \\
\hline $\mathrm{M}_{2}^{\prime}$ & $70.5 / 5.26$ & $\mathrm{C}_{2}-\mathrm{H}_{2}$ in 2-O-acetyl- $\beta$-D-mannopyranoside \\
\hline $\mathrm{X}_{2}$ & $72.6 / 3.03$ & $\mathrm{C}_{2}-\mathrm{H}_{2}$ in $\beta$-D-xylopyranoside \\
\hline $\mathrm{X}_{2}^{\prime}$ & 73.1/4.49 & $\mathrm{C}_{2}-\mathrm{H}_{2}$ in 2-O-acetyl- $\beta$-D-xylopyranoside \\
\hline$x_{3}$ & $73.8 / 3.22$ & $\mathrm{C}_{3}-\mathrm{H}_{3}$ in $\beta$-D-xylopyranoside \\
\hline $\mathrm{X}_{3}^{\prime}$ & $74.7 / 4.79$ & $\mathrm{C}_{3}-\mathrm{H}_{3}$ in 3-O-acetyl- $\beta$-D-xylopyranoside \\
\hline $\mathrm{X}_{4}$ & $75.3 / 3.52$ & $\mathrm{C}_{4}-\mathrm{H}_{4}$ in $\beta$-D-xylopyranoside \\
\hline $\mathrm{U}_{4}$ & $81.2 / 3.07$ & $\mathrm{C}_{4}-\mathrm{H}_{4}$ in 4-O-methyl- $\alpha$-D-glucuronic acid \\
\hline$X_{1(R)}$ & $97.1 / 4.24$ & $\mathrm{C}_{1}-\mathrm{H}_{1}$ in $\beta$-D-xylopyranoside or $\beta$-D-glucopyranoside $(\mathrm{R})$ \\
\hline $\mathrm{U}_{1}$ & $97.2 / 5.16$ & $\mathrm{C}_{1}-\mathrm{H}_{1}$ in 4-O-methyl- $\alpha$-D-glucuronic acid \\
\hline $\mathrm{X}_{1}^{\prime}$ & $99.4 / 4.49$ & $\mathrm{C}_{1}-\mathrm{H}_{1}$ in 2-O-acetyl- $\beta$-D-xylopyranoside \\
\hline$M_{1}$ & $100.6 / 4.63$ & $\mathrm{C}_{1}-\mathrm{H}_{1}$ in $(1 \rightarrow 4) \beta$-D-mannopyranoside \\
\hline $\mathrm{X}_{1} / \mathrm{X}^{\prime}{ }_{1}$ & $101.6 / 4.27$ & $\mathrm{C}_{1}-\mathrm{H}_{1}$ in $\beta$-D-xylopyranoside/3-O-acetyl- $\beta$-D-xylopyranoside \\
\hline $\mathrm{Gl}_{1}$ & $103.1 / 4.18$ & $\mathrm{C}_{1}-\mathrm{H}_{1}$ in $(1 \rightarrow 4) \beta$-D-glucopyranoside \\
\hline
\end{tabular}

(t), tentatively assigned; $\mathrm{R}$, reducing end.

obtained at the gel stage in DMSO- $d_{6}$ (Kim et al., 2008; Rencoret et al., 2009). The main lignin substructures identified are also shown. The different lignin and polysaccharide cross-signals assigned on the spectra are listed in Table 1. Important differences were observed in the spectra of the fungally degraded woods compared with the sound wood.

The spectrum of sound wood (Fig. 1a) showed signals of both lignin and polysaccharide moieties, including cellulose and hemicelluloses. However, the spectra of the white-rotted wood (Fig. 1b) showed the presence of only polysaccharide moieties and the absence of lignin moieties. A complete assignment of all the polysaccharide cross-signals was not possible because of overlapping of the different signals of cellulose and hemicellulose units. The E. cordifolia hemicelluloses included xylose (11\%) and lower amounts of uronic acids (5\%), mannose $(3 \%)$ and arabinose (2\%). However, several polysaccharide cross-signals could be identified in the spectrum of the sound and white-rotted woods shown in Fig. 1a and b. In addition to lignin removal, the NMR spectrum of the whiterotted wood also indicated the simultaneous disappearance of mannans $\left(M_{1}\right.$ and $\left.M_{2}^{\prime}\right)$, uronic acids $\left(U_{1}\right.$ and $\left.U_{4}\right)$ and a reduction of the xylan content with the complete disappearance of its $\left(C_{2}\right.$ and/or $\left.C_{3}\right)$ acetylated units $\left(X^{\prime}{ }_{1}\right.$, $\mathrm{X}_{2}^{\prime}$ and $\mathrm{X}^{\prime}{ }_{3}$ cross-signals), which were present in the spectrum of the sound wood. The above results indicate a parallel removal of the lignin and hemicelluloses by $G$. australe in such a way that the final material was enriched in cellulose and deacetylated hemicellulose. Note that cellulose is underestimated in the gel spectra because its crystalline moiety is 'silent' under solution NMR conditions, as revealed by comparison with solid-state ${ }^{13} \mathrm{C}$ NMR spectra (Martínez et al., 1991). These data confirmed that this fungus is a very potent and selective lignin degrader, which is able to decompose the entire lignin present in the E. cordifolia wood, as reported in previous studies (Martínez et al., 1991; 1995).

The HSQC spectrum of the brown-rotted wood (Fig. 1c) showed a totally divergent degradation pattern, character- 
Table 2. Abundances of lignin side-chain linkages and methoxyl groups, as per aromatic unit (and as percentage of total side-chains, in parenthesis), in the sound and brown-rotted E. cordifolia wood (calculated from the 2D-NMR spectra of Fig. 1A and C).

\begin{tabular}{lll}
\hline & Sound wood & Brown rot \\
\hline Linkage abundance: & & \\
$\beta-O-4^{\prime}$ aryl ethers (A) & $0.82(83)$ & $0.44(80)$ \\
$\beta-\beta^{\prime}$ resinols (B) & $0.11(12)$ & $0.07(12)$ \\
$\beta-5^{\prime}$ phenylcoumarans (C) & $0.02(2)$ & $0.01(2)$ \\
$\beta-1^{\prime}$ spirodienones (D) & $0.02(2)$ & $0.00(0)$ \\
$C_{\alpha}-$-oxidized $\beta-O-4^{\prime}$ substructures (E) & $0.01(1)$ & $0.03(6)$ \\
Methoxyl content & 2.77 & 2.24 \\
\hline
\end{tabular}

ized by the absence of practically all the polysaccharide moieties, while only the lignin polymer was present. The obtained data indicated that this polymer was not drastically modified by the brown-rot fungus, all the typical cross-signals of lignin remaining visible. This included well-resolved signals of $\beta-O-4^{\prime}(A)$ and $\beta-\beta^{\prime}$ (resinol-type, $B)$ side-chain linkages together with strong aromatic signals of syringyl (S) and guaiacyl (G) lignin units, whose relative intensities are apparently not strongly affected. To verify this point, the relative abundance of the main interunit linkages (given as per aromatic units, and as percentage of total side-chains involved) were calculated from the HSQC spectra (Table 2). These data indicated that brownrot decay only slightly increased the relative abundances of the $\beta-O-4^{\prime}$ substructures (from $84 \%$ to $86 \%$ of total side-chains) but did not modify that of the $\beta-\beta^{\prime}$ substructures (12\% of total side-chains). Minor spirodienones (D) found in sound wood ( $2 \%$ of side-chains) were not detected after the brown-rot decay.

On the other hand, a small increase of oxygenated moieties in the brown-rotted wood was evidenced in the HSQC spectrum by the small signal corresponding to aliphatic ${ }^{13} \mathrm{C}^{-1}{ }^{-1} \mathrm{H}_{\beta}$ correlation in $\mathrm{C}_{\alpha}$-oxidized $\beta-\mathrm{O}-4^{\prime}$ substructures $(\mathrm{E})$. The aromatic ${ }^{13} \mathrm{C}_{2,6^{-}}{ }^{-} \mathrm{H}_{2,6}$ correlation signal in $\mathrm{C}_{\alpha}$-oxidized $\mathrm{S}$ units $\left(\mathrm{S}^{\prime}\right)$ also showed comparatively higher intensity. An estimation of $12 \%$ oxidized $S$ units in the sound wood, and $20 \%$ in the brown-rotted wood was obtained. The existence of carbonyl and carboxyl groups in brown-rotted wood has been also shown by solid-state ${ }^{13} \mathrm{C}$ NMR and other techniques (Martínez et al., 1991; Sun et al., 2009; Koenig et al., 2010). This indicates that some oxidative alterations in the lignin structure occurred during brown-rot decay, in agreement with the pyrolysis results described below. Moreover, two new aromatic crosssignals ( $M C$ and $M C^{\prime}$ ) were found in the spectrum of the brown-rotted wood (Fig. 1c). The same signals have been reported in HSQC spectra of brown-rotted oak wood, obtained using high-resolution magic-angle spinning (HRMAS) NMR (Koenig et al., 2010). We assigned these two signals to aromatic structures derived from the demethylation/demethoxylation of $S$ units (yielding 5-hydroxyguaiacyl units that can form new 5-O-aryl ether bonds), a modification reaction that was further confirmed by pyrolysis (yielding 3-methoxycatechols). However, more studies are necessary for the unambiguous assignment of the two new signals. In addition to the presence of these new aromatic units, which represented $14 \%$ of lignin units (Table 3 ), and the absence of $p$-hydroxyphenyl (H) units, the spectrum of the brown-rotted wood also showed a small increase of the $S / G$ ratio (from 3.2 in sound wood to 4.2 after brown-rot decay).

\section{Side-chain linkages and methoxyl removal in brown-rot decay}

The relative abundances of the main lignin linkages remained largely unchanged after brown-rot decay, as shown in the previous section. However, a comparison of the lignin side-chain (involved in $\beta-O-4^{\prime}, \beta-\beta^{\prime}$ and other linkages) and methoxyl cross-signals on an aromatic unit basis indicates around $45 \%$ depletion of the above linkages and near $20 \%$ depletion of methoxyls. This agrees with the Yelle and colleagues (2008b) hypothesis suggesting that lignin attack by hydroxyl-free radical, the main wood decay agent in brown rot (Suzuki et al., 2006; Martínez et al., 2009a), should result in simultaneous breakdown of both methoxyl groups and inter-unit ether linkages. Taking into account the decrease of methoxyl groups, the depletion of side-chain linkages in E. cordifolia lignin, on a methoxyl basis, amounts to only $30 \%$. This observation contrasts with Yelle and colleagues (2008b) who reported a depletion of more than $70 \%$ of the lignin side-chain linkages (on a methoxyl basis) in white spruce (Picea glauca) wood degraded in vitro with the brown-rot fungus Gloeophyllum trabeum. In fact, some of the lignin side-chain signals that are clearly visible in the HSQC spectrum of the brown-rotted E. cordifolia wood (Fig. 1C) were hardly detectable in the HSQC spectrum of the $G$. trabeum rotted $P$. glauca wood. Therefore, these authors concluded that extensive ligninolysis (i.e. degradation of lignin inter-unit linkages) was produced by brown-rot fungi

Table 3. Ratio of unmodified (H, G and S) and S-type demethylated (MC) lignin units in the sound and brown-rotted E. cordifolia wood, as estimated from 2D-NMR, Py-GC/MS and Py/TBAH analyses (MC/ $[\mathrm{MC}+\mathrm{S}]$ is shown in parentheses).

\begin{tabular}{|c|c|c|}
\hline & \multicolumn{2}{|c|}{$\mathrm{H}: \mathrm{G}: \mathrm{S}: \mathrm{MC}$ ratio (S-demethylation as $\%$ ) } \\
\hline & Sound wood & Brown-rotted wood \\
\hline 2D-NMR & 0:24:76:0 (0\%) & 0:17:69:14 (18\%) \\
\hline Py-GC/MS & $3: 25: 68: 4^{a}(5 \%)$ & $3: 21: 62: 12^{a}(16 \%)$ \\
\hline $\mathrm{Py} / \mathrm{TBAH}$ & $2: 25: 72: 0(1 \%)$ & $2: 23: 69: 6(8 \%)$ \\
\hline
\end{tabular}

a. Small amounts of demethylated $G$ units were also found by Py-GC/MS of sound (1\%) and brown-rotted (2\%) woods. 
yielding a material that is not longer recognized as lignin. This contrasts with the typical lignin spectrum reported here (Fig. 1c), as well as with the recently reported HRMAS analysis of naturally brown-rotted oak wood (Koenig et al., 2010). Moreover, no signals assigned to new (aryl-aryl or side-chain) linkages, which may be formed to replace the $>70 \%$ degraded side-chain linkages in lignin, were detected in the HSQC spectrum of the in vitro degraded wood (Yelle et al., 2008b). In contrast, the two new aromatic signals ( $\mathrm{MC}$ and $\mathrm{MC}^{\prime}$ ) found in the HSQC spectrum of the E. cordifolia wood after natural brown-rot decay could include correlations of new aryl-O-aryl ether linkages formed after demethylation/ demethoxylation of $S$ units (as discussed in the next section).

The atypical decay pattern described by Yelle and colleagues $(2008 b)$ cannot be due to a more extensive decay, since the weight losses were similar to those found on E. cordifolia wood (62-64\%). Interestingly, the typical lignin spectra reported by Koenig and colleagues (2010) for brown-rotted oak by Laetiporus sulphureus were also obtained from naturally decayed wood. This suggest that differences between laboratory and field conditions, the latter resulting in more selective brown-rot removal of polysaccharides (as shown by NMR) could explain the above discrepancies, more than the type of wood or the fungal species. A similar situation was produced when the authors failed to reproduce the selective white-rot decay pattern by $G$. australe under laboratory conditions, using Austral (E. cordifolia) and European (Fagus sylvatica) woods (Barrasa et al., 1992; Bechtold et al., 1993).

\section{Confirmation of lignin demethylation in brown-rot decay: $P y$-GC/MS and Py/TBAH analyses}

To obtain more detailed insight into the chemical modifications of the lignin structure during fungal decay, the sound and rotted wood samples were subjected to Py-GC/MS. The white-rotted wood (pyrogram not shown) released only polysaccharide-derived compounds with only traces of lignin-derived phenols being present, in agreement with previous studies (Mulder et al., 1991). Figure 2 shows the pyrogram of the brown-rotted wood that was dominated by peaks of phenolic compounds derived from the lignin moiety, confirming the large extent of removal of polysaccharides shown by NMR, while that of the sound wood showed compounds arising from both the polysaccharide and lignin moieties. The complete series of Py-GC/MS compounds identified in the sound and brown-rotted woods are included in Fig. S2 and Table S1. In both samples, S- and G-type phenols were released, with a predominance of the former and similar distribution pattern, together with minor $\mathrm{H}$-type phenols. Simultaneously, a small increase in the abundances of syringic acid (peak 48) and other phenolic acids was observed confirming that some oxidative alteration of lignin side-chains occurred during brown-rot decay, as shown also by NMR. More interesting, high abundances of 5-hydroxyguaiacyl type compounds were released upon Py-GC/MS of the brown-rotted wood, as shown in Fig. 2 that includes the chemical structure of the main one (3-methoxycatechol, peak 10) together with that of its counterpart in unmodified lignin (syringol, peak 15). The other 3-methoxycatechol type compounds include the 5-methyl derivative (peak 16), followed by its 5-vinyl, 5-ethyl and 5-propenyl derivatives. These compounds can directly derive from demethylated (i.e. 5-hydroxy) $S$ moieties, as reported for archaeological wood (van Bergen et al., 2000; Lucejko et al., 2009). However similar compounds will also be obtained if, after initial demethylation, pyrolysis-labile aryl-O-aryl ether linkages are formed, as suggested above (see $\mathrm{MC}$ and $\mathrm{MC}^{\prime}$ units in Fig. 1), as a result of the phenoloxidase activity of brown-rot fungi (Martínez et al., 2009a).

Lignin demethylation during brown-rot decay was also investigated by Py/TBAH (del Río et al., 1996). Pyrolysis in the presence of the classical alkylating agent, tetramethylammonium hydroxide (TMAH), has been used to analyse fungal rotted woods (del Río et al., 1998; Filley et al., 2002). However, the butyl ethers of the hydroxyl groups (formed after breakdown of alkyl-O-aryl ether linkages by Py/TBAH or pre-existing in lignin) are more easily identified than the methyl ethers formed by $\mathrm{Py} / \mathrm{TMAH}$. The Py/TBAH chromatogram of the brownrotted wood is shown in Fig. 3 , including the chemical structures of the main demethylation product discussed below (peak MC12) and its counterpart in unmodified lignin (peak S12). The chromatogram of the sound wood, the chemical structures of all the released compounds and their relative molar areas are provided in Figs S3 and S4 and Table S2 respectively. Py/TBAH of sound and brown-rotted woods released predominantly the butylated derivatives of G- and S-type compounds, together with minor amounts of $\mathrm{H}$-type derivatives. However, the butyl derivatives of 3-methoxycatecholtype (MC) compounds, derived from demethylated lignin $S$ units, were also released from the brown-rotted wood in important amounts. Among them, 3,4-dibutoxy-5methoxybenzoic acid butyl ester (peak MC12) was the main demethylation product as mentioned above, followed by 3,4-dibutoxy-5-methoxybenzaldehyde (peak MC4), two 3,4-dibutoxy-5-methoxyphenylpropanones (peaks MC8 and MC10) and 1,2-dibutoxy-3methoxybenzene (peak MC1).

The ratio between the different types of aromatic compounds deriving from the typical $\mathrm{H}, \mathrm{G}$ and $\mathrm{S}$ lignin units, as well as from the MC-type units discussed above, are shown in Table 3 after both Py-GC/MS and Py/TBAH 


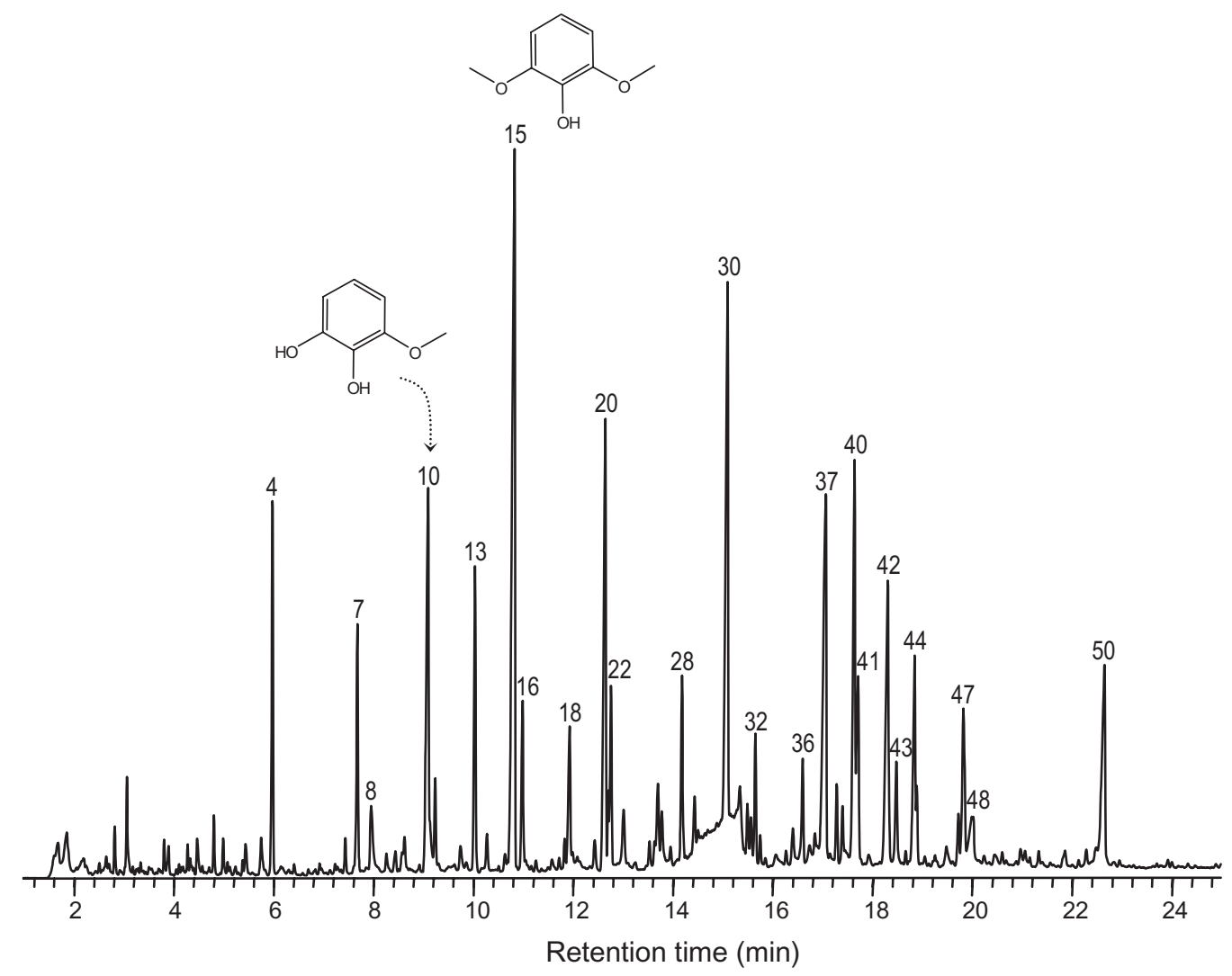

Fig. 2. Py-GC/MS of E. cordifolia wood after brown-rot fungal decay under environmental conditions. The chemical structures of the main lignin demethylation product (peak 10) and its counterpart in unmodified lignin (peak 15) are shown. Peak identification (relative molar area $\geq$ 1\%): 4, guaiacol; 7, 4-methylguaiacol; 8, catechol; 10, 3-methoxycatechol; 13, 4-vinylguaiacol; 15, syringol; 16, 5-methyl-3-methoxycatechol; 18, vanillin; 20, 4-methylsyringol; 22, trans-isoeugenol; 28, 4-ethylsyringol; 30, 4-vinylsyringol; 32, 4-allylsyringol; 36, cis-4-propenylsyringol; 37, syringaldehyde; 40, trans-4-propenylsyringol; 41, homosyringaldehyde; 42, acetosyringone; 43, coniferaldehyde; 44 , syringylacetone; 47 , propiosyringone; 48, syringic acid; and 50, trans-sinapaldehyde. For Py-GC/MS of the control wood, and identification of minor peaks, see Fig. S2 and Table S1.

analyses of the brown-rotted and the sound wood. These data agree with those obtained from 2D-NMR, also included in Table 3, although the minor $\mathrm{H}$ units are probably below the detection level of 2D-NMR. Py-GC/MS showed some demethylation products in the sound wood (that could be formed during thermal depolymerization since they were not detected after alkaline depolymerization in Py/TBAH nor in the NMR spectrum). However, they are much less abundant than in the brown-rotted wood. Interestingly, a preferential demethylation of the $S$ units was observed after the different analyses, with values that ranged $8-18 \%$ depending of the estimation procedure. Methoxycatechol had been previously detected after Py-GC/MS of both sound and brown-rotted E. cordifolia wood (Mulder et al., 1991), but no information was provided on its increase during wood decay. However, the increased occurrence of 3-methoxycatechol type Py-GC/MS compounds, and the detection of similar diagnostic compounds after Py/TBAH (being absent from the sound wood) clearly indicates that some demethylation of lignin occurred during brown-rot decay, in agreement with the classical work of Kirk (1975) and other studies (Filley et al., 2002) including radiolabelling demonstration (Niemenmaa et al., 2008). As mentioned above, lignin demethylation would result in new phenolic units that could experiment new oxidation reactions during fungal attack resulting in new aryl-O-aryl ether linkages by radical coupling. It is interesting that Klason lignin estimation in the sound and brown-rotted E. cordifolia wood (62\% weight loss) revealed no significant lignin degradation (only $\sim 1 \%$ of the initial lignin) indicating that the changes revealed by the 2D-NMR and pyrolysis analyses discussed above are due to fungal reworking (modification) of the polymer (including the new aryl-O-aryl ether linkages) more than to complete degradation of some lignin moieties.

\section{Wood rotting in the light of new genomic/transcriptomic information}

The recent sequencing of the first brown-rot fungal genome (Martínez et al., 2009a) has provided new clues 


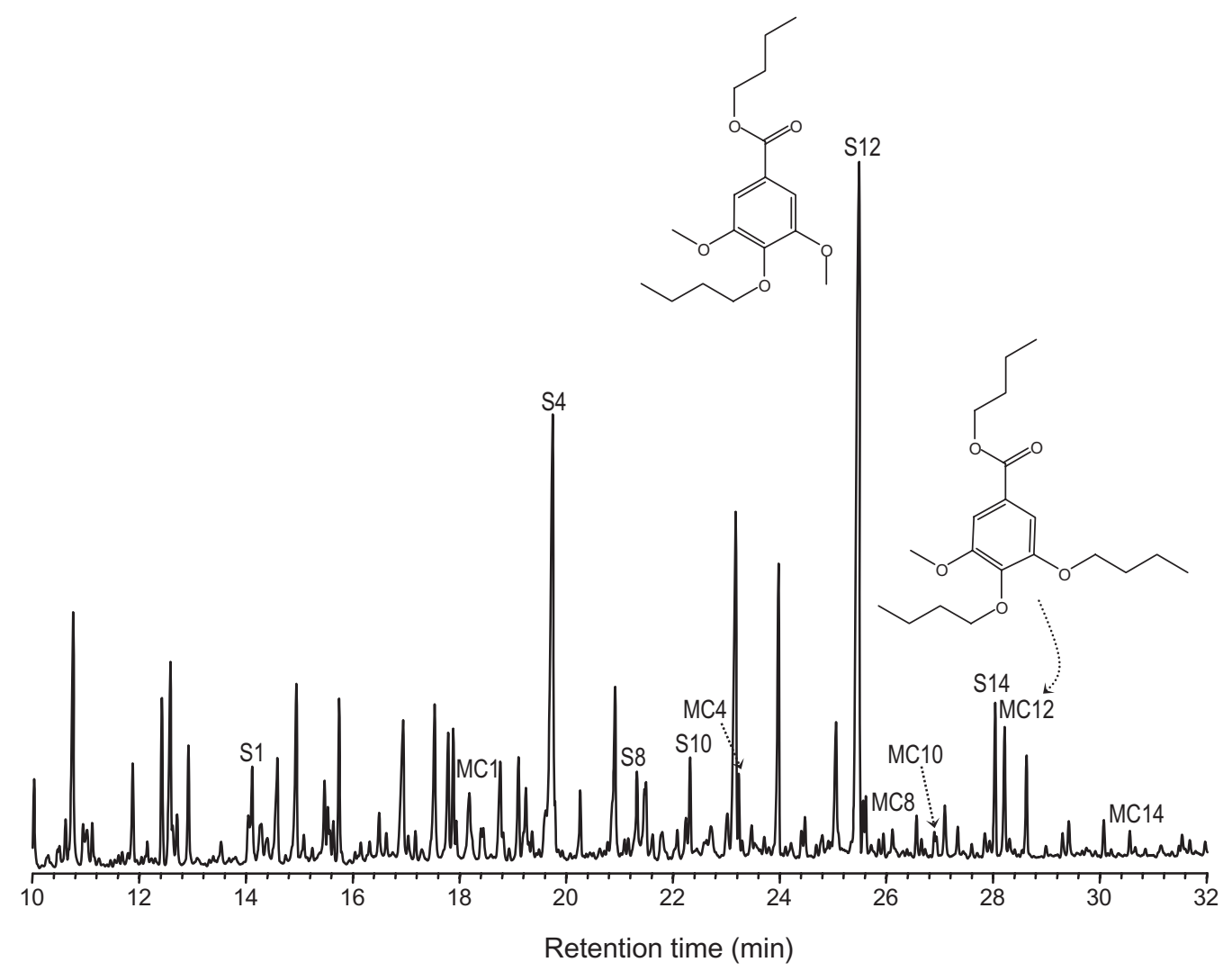

Fig. 3. Py/TBAH of E. cordifolia wood after brown-rot fungal decay under environmental conditions. The structures of the main lignin demethylation product (MC12) and its counterpart in unmodified lignin (S12) are depicted, and those of other compounds are shown in Fig. S4. Identification of peaks from demethylated lignin and their unmodified counterparts: S1, 1-butoxy-2,6-dimethoxybenzene; MC1, 1,2-dibutoxy-3-methoxybenzene; S4, 3,5-dimethoxy-4-butoxybenzaldehyde; S8, 3,5-dimethoxy-4-butoxyphenylacetone; S10,

1-(3,5-dimethoxy-4-butoxyphenyl)propan-1-one; MC4, 3,4-dibutoxy-5-methoxybenzaldehyde; S12, 3,5-dimethoxy-4-butoxybenzoic acid butyl ester; MC8, 3,4-dibutoxy-5-methoxyphenylacetone; MC10, 1-(3,4-dibutoxy-5-methoxyphenyl)-propan-1-one; S14,

3,5-dimethoxy-4-butoxy-benzenepropanoic acid butyl ester; MC12, 3,4-dibutoxy-5-methoxybenzoic acid butyl ester; and MC14, 3,4-dibutoxy-5-methoxybenzenepropanoic acid butyl ester. For Py/TBAH of the control wood, and identification of minor peaks, see Fig. S3 and Table S2.

about how this decay process takes place, although differences between brown-rot fungi probably exist (as revealed by $P$. placenta and $G$. trabeum genome and EST information currently available in GenBank). In this context, the above discussed lignin demethylation could play a central role since it releases methanol, and the secretomic and transcriptomic studies associated to the brown-rot genome have shown that methanol oxidase genes are overexpressed when the fungus degrades cellulose.

In the light of the information currently available, it is therefore possible to infer that brown-rot fungi most probably produces $\mathrm{H}_{2} \mathrm{O}_{2}$ using methanol as the reducing substrate of methanol oxidase, an enzyme that has been investigated by Daniel and colleagues (2007) in relation to brown rot. Then, $\mathrm{H}_{2} \mathrm{O}_{2}$ would be reduced to hydroxyl radical by ferrous iron formed in hydroquinone redoxcycling (Suzuki et al., 2006) or by other enzymatic mechanisms. The hydroxyl-free radical would be the main agent responsible for the oxidative depolymerization of cellulose, since a reduced number of cellulases (but a variety of hemicellulases) has been found in the brown-rot fungal genome (Martínez et al., 2009a). At the same time it promotes partial demethylation of lignin, a reaction that has been proved using ${ }^{13} \mathrm{C}$-TMAH thermochemolysis (Arantes et al., 2009).

A very recent study (Vanden Wymelenberg et al., 2010) has shown that methanol oxidase is also overexpressed in the white-rot fungus $P$. chrysosporium. Demethylation is also a common side-reaction after one-electron oxidation of lignin units to their cation radicals by white-rot fungi and their ligninolytic peroxidases (Ander et al., 1992; Martínez et al., 2005). These results suggest that several oxidases (such as glyoxal oxidase and methanol oxidase) are involved in $\mathrm{H}_{2} \mathrm{O}_{2}$ production by $P$. chrysosporium using different lignocellulose-derived compounds as substrates. Most probably, the same happens in brown-rot fungi, since expression of aryl-alcohol oxidase (and other $\mathrm{H}_{2} \mathrm{O}_{2}$ - 
producing oxidases) has been found in $P$. placenta, in addition to the main methanol oxidase (Martínez et al., 2009a). In this context, it is interesting to remark that $\mathrm{H}_{2} \mathrm{O}_{2}$ production is a common step in both white and brown-rot decay of wood by fungi: in the first case as the oxidizing substrate of ligninolytic peroxidases, and for hydroxyl radical generation in the second case.

\section{Experimental procedures}

\section{Materials and general analyses}

Samples of E. cordifolia (Chilean 'ulmo'; order Oxalidales, family Cunoniaceae) wood naturally degraded by white and brown-rot basidiomycetes were collected at two locations on Chiloe Island, in the Chilean rain forest (Martínez et al., 1991). The samples include: (i) sound wood, (ii) extremely delignified wood by the white-rot fungus $G$. australe and (iii) wood decayed by an unidentified brown-rot basidiomycete. Sound and decayed wood samples were dried, milled in a Janke and Kunkel mill and passed through a 20-mesh sieve. In addition to their macroscopic aspect (such as colour and texture) and eventual presence of fruit bodies, microscopic examination using the selective safranin-Astra blue staining (Srebotnik and Messner, 1994) and chemical analyses including Klason lignin content, polysaccharide composition (neutral sugars by GC as alditol acetates, and uronic acids by the carbazole method), and other wood constituents (ashes, extractives and water-soluble material) (Martínez et al., 1991) were used to confirm and characterize the brown and white-rot decay patterns of the samples analysed.

\section{D-NMR}

Roughly $100 \mathrm{mg}$ of finely ball-milled wood was suspended in $0.75 \mathrm{ml}$ of DMSO- $d_{6}$ in the NMR tube and sonicated for $10 \mathrm{~min}$ in an ultrasonic bath (Ultrasons JS 3000513 from Selecta, with a frequency of $40 \mathrm{kHz}$ and $150 \mathrm{~W}$ power consumption), until a homogeneous gel was formed. 2D-NMR spectra were recorded at $25^{\circ} \mathrm{C}$ on a Bruker AVANCE $500 \mathrm{MHz}$ equipped with a z-gradient triple resonance probe. For the HSQC experiments, the spectral widths were $5000 \mathrm{~Hz}$ and $25000 \mathrm{~Hz}$ for the ${ }^{1} \mathrm{H}$ - and ${ }^{13} \mathrm{C}$-dimensions respectively. The number of collected complex points was 2048 for ${ }^{1} \mathrm{H}$-dimension with a recycle delay of $5 \mathrm{~s}$. The number of transients was 64, and 256 time increments were always recorded in ${ }^{13} \mathrm{C}$-dimension. The ${ }^{1} J_{\mathrm{CH}}$ used was $140 \mathrm{~Hz}$. The J-coupling evolution delay was set to $3.2 \mathrm{~ms}$. Squared cosine-bell apodization function was applied in both dimensions. Prior to Fourier transform, the data matrixes were zero filled up to 1024 points in the ${ }^{13} \mathrm{C}$-dimension. The central DMSO peak $\left(\delta_{\mathrm{C}} 39.5 ; \delta_{\mathrm{H}} 2.50\right)$ was used as chemical shift reference. HSQC cross-signals of lignin were assigned by comparing them with previously reported data (Ralph et al., 1999; 2004; Liitiä et al., 2003; Capanema et al., 2004; 2005; Ibarra et al., 2007a; 2007b; del Río et al., 2008; Martínez et al., 2008; Rencoret et al., 2008). Some wood polysaccharide signals were also assigned (Yelle et al., 2008a; Rencoret et al., 2009; Kim and Ralph, 2010).
A semiquantitative analysis of the intensities of the HSQC cross-signal intensities was performed (Heikkinen et al., 2003; Liitiä et al., 2003; Zhang and Gellerstedt, 2007). First, cross-signal integration was performed separately for the different regions of the spectra, which contain chemically analogous carbon-proton pairs. In the aliphatic oxygenated region, the relative abundance of the different inter-unit linkages were estimated from $\mathrm{C}_{\alpha}-\mathrm{H}_{\alpha}$ correlations, and the relative abundance of side-chains involved in the different interunit linkages were calculated. In the aromatic region, $\mathrm{C}_{2,6}-\mathrm{H}_{2,6}$ correlations from $\mathrm{S}$ units, $\mathrm{C}_{2}-\mathrm{H}_{2}$ plus $\mathrm{C}_{6}-\mathrm{H}_{6}$ correlations from $\mathrm{G}$ units, and $\mathrm{C}_{6}-\mathrm{H}_{6}$ correlations from $\mathrm{MC}$ units were used to estimate the $\mathrm{G}: \mathrm{S}: \mathrm{MC}$ ratio of lignin. Finally, the abundances of the different interunit linkages were referred to the number of aromatic units, to obtain a comparative estimation of their removal during fungal decay.

\section{$P y-G C / M S$ and Py/TBAH}

Py-GC/MS of wood (approximately $1 \mathrm{mg}$ ) was performed with a 2020 micro-furnace pyrolyser (Frontier Laboratories) connected to an Agilent 6890 GC/MS system equipped with a DB-5MS (Agilent J\&W) fused-silica capillary column (30 $\mathrm{m} \times 0.25 \mathrm{~mm}$ i.d., $0.25 \mu \mathrm{m}$ film thickness) and an Agilent 5973 mass selective detector (El at $70 \mathrm{eV}$ ). The pyrolysis was performed at $500^{\circ} \mathrm{C}$. The oven temperature was programmed from $40^{\circ} \mathrm{C}(1 \mathrm{~min})$ to $300^{\circ} \mathrm{C}$ at $6^{\circ} \mathrm{C} \mathrm{min}^{-1}$ (10 min). Helium was used as carrier gas $\left(1 \mathrm{ml} \mathrm{min}{ }^{-1}\right)$. For Py/TBAH, $1 \mathrm{mg}$ of wood sample was mixed with approximately $5 \mu \mathrm{l}$ of TBAH (25\%, w/w, methanol solution) and the pyrolysis was carried out as described above. The compounds were identified by fragmentography and by comparing their mass spectra with those of the Wiley and NIST libraries and reported in the literature (Faix et al., 1990; Ralph and Hatfield, 1991; del Río et al., 1996). Peak molar areas were calculated for the ligninderived products, the summed areas were normalized to 100 , and the data for two repetitive analyses were averaged and expressed as percentages.

\section{Acknowledgements}

This study has been supported by the BIORENEW EU-project (NMP2-CT-2006-026456), the CSIC project 201040E075, and the Spanish projects ELLE (AGL200800709) and RAPERO (BIO2008-01533). The authors thank Aldo E. González (CBM, CSIC, Madrid, Spain) and Rafael Vicuña (Pontificia University, Santiago de Chile) for his help in the collection and identification of wood samples; and José M. Barrasa (Alcalá University, Madrid, Spain) for his help the microscopic examinations.

\section{References}

Ander, P., Hatakka, A.I., Lundell, T.K., Pettersson, B., Stalmasek, M., and Volc, J. (1992) Demethoxylation of lignin by lignin peroxidases from Phlebia radiata and Phanerochaete chrysosporium. In Ligno-Cellulosics. Science, Technology, Development and Use. Kennedy, J.F., Phillips, G.O., and Williams, P.A. (eds). New York, NY, USA: Ellis Horwood, pp. 109-119. 
Arantes, V., Qian, Y.H., Kelley, S.S., Milagres, A.M.F., Filley, T.R., Jellison, J., and Goodell, B. (2009) Biomimetic oxidative treatment of spruce wood studied by pyrolysismolecular beam mass spectrometry coupled with multivariate analysis and ${ }^{13} \mathrm{C}$-labeled tetramethylammonium hydroxide thermochemolysis: implications for fungal degradation of wood. J Biol Inorg Chem 14: 1253-1263.

Baldrian, P., and Valaskova, V. (2008) Degradation of cellulose by basidiomycetous fungi. FEMS Microbiol Rev 32: 501-521.

Barrasa, J.M., González, A.E., and Martínez, A.T. (1992) Ultrastructural aspects of fungal delignification of Chilean woods by Ganoderma australe and Phlebia chrysocrea: a study of natural and in vitro degradation. Holzforschung 46: $1-8$.

Bechtold, R., González, A.E., Almendros, G., Martínez, M.J., and Martínez, A.T. (1993) Lignin alteration by Ganoderma australe and other white-rot fungi after solid-state fermentation of beech wood. Holzforschung 47: 91-96.

van Bergen, P.F., Poole, I., Ogilvie, T.M.A., Caple, C., and Evershed, R.P. (2000) Evidence for demethylation of syringyl moieties in archaeological wood using pyrolysisgas chromatography/mass spectrometry. Rapid Commun Mass Spectrom 14: 71-79.

Capanema, E.A., Balakshin, M.Y., and Kadla, J.F. (2004) A comprehensive approach for quantitative lignin characterization by NMR spectroscopy. J Agric Food Chem 52: 1850-1860.

Capanema, E.A., Balakshin, M.Y., and Kadla, J.F. (2005) Quantitative characterization of a hardwood milled wood lignin by nuclear magnetic resonance spectroscopy. J Agric Food Chem 53: 9639-9649.

Daniel, G., Volc, J., Filonova, L., Plihal, O., Kubátová, E., and Halada, P. (2007) Characteristics of Gloeophyllum trabeum alcohol oxidase, an extracellular source of $\mathrm{H}_{2} \mathrm{O}_{2}$ in brown rot decay of wood. Appl Environ Microbiol 73: 6241-6253.

Faix, O., Meier, D., and Fortmann, I. (1990) Thermal degradation products of wood. Holz Roh Werkst 48: 281-285.

Filley, T.R., Cody, G.D., Goodell, B., Jellison, J., Noser, C., and Ostrofsky, A. (2002) Lignin demethylation and polysaccharide decomposition in spruce sapwood degraded by brown rot fungi. Org Geochem 33: 111-124.

Fujimoto, A., Matsumoto, Y., Chang, H.M., and Meshitsuka, G. (2005) Quantitative evaluation of milling effects on lignin structure during the isolation process of milled wood lignin. $J$ Wood Sci 51: 89-91.

Gellerstedt, G., and Henriksson, G. (2008) Lignins: major sources, structure and properties. In Monomers, Polymers and Composites from Renewable Resources. Belgacem, M., and Gandini, A. (eds). Amsterdam, the Netherlands: Elsevier, pp. 201-224.

Heikkinen, S., Toikka, M.M., Karhunen, P.T., and Kilpeläinen, I.A. (2003) Quantitative 2D HSQC (Q-HSQC) via suppression of J-dependence of polarization transfer in NMR spectroscopy: application to wood lignin. J Am Chem Soc 125: 4362-4367.

Higuchi, T. (1997) Biochemistry and Molecular Biology of Wood. London, UK: Springer Verlag.

Ibarra, D., Chávez, M.I., Rencoret, J., del Río, J.C., Gutiérrez, A., Romero, J., et al. (2007a) Lignin modification during Eucalyptus globulus kraft pulping followed by totally chlo-
Fungal removal of wood lignin or polysaccharides

rine free bleaching: a two-dimensional nuclear magnetic resonance, Fourier transform infrared, and pyrolysis-gas chromatography/mass spectrometry study. J Agric Food Chem 55: 3477-3499.

Ibarra, D., Chávez, M.I., Rencoret, J., del Río, J.C., Gutiérrez, A., Romero, J., et al. (2007b) Structural modification of eucalypt pulp lignin in a totally chlorine free bleaching sequence including a laccase-mediator stage. Holzforschung 61: 634-646.

Karhunen, P., Rummakko, P., Sipila, J., Brunow, G., and Kilpeläinen, I. (1995) Dibenzodioxocins - a novel type of linkage in softwood lignins. Tetrahedron Lett 36: 169-170.

Kilpelainen, I., Xie, H., King, A., Granstrom, M., Heikkinen, S., and Argyropoulos, D.S. (2007) Dissolution of wood in ionic liquids. J Agric Food Chem 55: 9142-9148.

Kim, H., and Ralph, J. (2010) Solution-state 2D NMR of ball-milled plant cell wall gels in DMSO- $d_{6} /$ pyridine- $d_{5}$. Org Biomol Chem 8: 576-591.

Kim, H., Ralph, J., and Akiyama, T. (2008) Solution-state 2D NMR of ball-milled plant cell wall gels in DMSO- $d_{6}$. Bioenerg Res 1: 56-66.

Kirk, T.K. (1975) Effects of brown-rot fungus Lenzites trabea on lignin of spruce wood. Holzforschung 29: 99-107.

Kishimoto, T. (2009) Synthesis of lignin model compounds and their application to wood research. Mokuzai Gakkaishi 55: 187-197.

Koenig, A.B., Sleighter, R.L., Salmon, E., and Hatcher, P.G. (2010) NMR structural characterization of Quercus alba (white oak) degraded by the brown rot fungus, Laetiporus sulphureus. J Wood Chem Technol 30: 61-85.

Liitiä, T.M., Maunu, S.L., Hortling, B., Toikka, M., and Kilpeläinen, I. (2003) Analysis of technical lignins by two- and three-dimensional NMR spectroscopy. J Agric Food Chem 51: 2136-2143.

Lu, F.C., and Ralph, J. (2003) Non-degradative dissolution and acetylation of ball-milled plant cell walls: highresolution solution-state NMR. Plant J 35: 535-544.

Lucejko, J.J., Modugno, F., Ribechini, E., and del Río, J.C. (2009) Characterisation of archaeological waterlogged wood by pyrolytic and mass spectrometric techniques. Anal Chim Acta 654: 26-34.

Martínez, A.T., González, A.E., Valmaseda, M., Dale, B.E., Lambregts, M.J., and Haw, J.F. (1991) Solid-state NMR studies of lignin and plant polysaccharide degradation by fungi. Holzforschung 45 (Suppl.): 49-54.

Martínez, A.T., Barrasa, J.M., Martínez, M.J., Almendros, G., Blanco, M., and González, A.E. (1995) Ganoderma australe: a fungus responsible for extensive delignification of some Austral hardwoods. In Ganoderma. Systematics, Phytopathology and Pharmacology. Buchanan, P.K., Hseu, R.S., and Moncalvo, J.M. (eds). Taipei, Taiwan: National Taiwan University, pp. 67-77.

Martínez, D., Larrondo, L.F., Putnam, N., Gelpke, M.D., Huang, K., Chapman, J., et al. (2004) Genome sequence of the lignocellulose degrading fungus Phanerochaete chrysosporium strain RP78. Nat Biotechnol 22: 695-700.

Martínez, A.T., Speranza, M., Ruiz-Dueñas, F.J., Ferreira, P., Camarero, S., Guillén, F., et al. (2005) Biodegradation of lignocellulosics: microbiological, chemical and enzymatic aspects of fungal attack to lignin. Intern Microbiol 8: 195204. 
Martínez, A.T., Rencoret, J., Marques, G., Gutiérrez, A., Ibarra, D., Jiménez-Barbero, J., and del Río, J.C. (2008) Monolignol acylation and lignin structure in some nonwoody plants: a 2D NMR study. Phytochemistry 69: 28312843.

Martínez, A.T., Ruiz-Dueñas, F.J., Martínez, M.J., del Río, J.C., and Gutiérrez, A. (2009a) Enzymatic delignification of plant cell wall: from nature to mill. Curr Opin Biotechnol 20: 348-357.

Martínez, D., Challacombe, J., Morgenstern, I., Hibbett, D.S., Schmoll, M., Kubicek, C.P., et al. (2009b) Genome, transcriptome, and secretome analysis of wood decay fungus Postia placenta supports unique mechanisms of lignocellulose conversion. Proc Natl Acad Sci USA 106: 19541959.

Mulder, M., Pureveen, J.B.M., Boon, J.J., and Martínez, A.T. (1991) An analytical pyrolysis mass spectrometry study of Eucryphia cordifolia wood decayed by white-rot and brownrot fungi. J Anal Appl Pyrolysis 19: 175-191.

Niemenmaa, O., Uusi-Rauva, A., and Hatakka, A. (2008) Demethoxylation of $\left[\mathrm{O}^{14} \mathrm{CH}_{3}\right]$-labelled lignin model compounds by the brown-rot fungi Gloeophyllum trabeum and Poria (Postia) placenta. Biodegradation 19: 555-565.

Otjen, L., and Blanchette, R.A. (1986) A discussion of microstructural changes in wood during decomposition by white rot basidiomycetes. Can J Bot 64: 905-911.

Ragauskas, A.J., Williams, C.K., Davison, B.H., Britovsek, G., Cairney, J., Eckert, C.A., et al. (2006) The path forward for biofuels and biomaterials. Science 311: 484-489.

Ralph, J., and Hatfield, R.D. (1991) Pyrolysis-GC-MS characterization of forage materials. J Agric Food Chem 39: 1426-1437.

Ralph, J., Marita, J.M., Ralph, S.A., Hatfield, R.D., Lu, F., Ede, R.M., et al. (1999) Solution-state NMR of lignin. In Advances in Lignocellulosics Characterization. Argyropoulos, D.S. (ed.). Atlanta, GA, USA: Tappi Press, pp. 55108.

Ralph, S.A., Ralph, J., and Landucci, L. (2004) NMR database of lignin and cell wall model compounds. US Forest Prod. Lab., One Gifford Pinchot Dr., Madison, WI [WWW document]. URL http://ars.usda.gov/Services/docs.htm? docid $=10491$.

Rencoret, J., Marques, G., Gutiérrez, A., Ibarra, D., Li, J., Gellerstedt, G., et al. (2008) Structural characterization of milled wood lignin from different eucalypt species. Holzforschung 62: 514-526.

Rencoret, J., Marques, G., Gutiérrez, A., Nieto, L., Santos, I., Jiménez-Barbero, J., et al. (2009) HSQC-NMR analysis of lignin in woody (Eucalyptus globulus and Picea abies) and non-woody (Agave sisalana) ball-milled plant materials at the gel state. Holzforschung 63: 691-698.

del Río, J.C., Martín, F., and González-Vila, F.J. (1996) Thermally assisted hydrolysis and alkylation as a novel pyrolytic approach for the structural characterization of natural biopolymers and geomacromolecules. Trends Anal Chem 15: $70-79$.

del Río, J.C., McKinney, D.E., Knicker, H., Nanny, M.A., Minard, R.D., and Hatcher, P.G. (1998) Structural characterization of bio- and geo-macromolecules by off-line thermochemolysis with tetramethylammonium hydroxide. J Chromatogr A 823: 433-448. del Río, J.C., Gutiérrez, A., Martínez, M.J., and Martínez, A.T. (2001) Py-GC-MS study of Eucalyptus globulus wood treated with different fungi. J Anal Appl Pyrolysis 58/59: 441-453.

del Río, J.C., Speranza, M., Gutiérrez, A., Martínez, M.J., and Martínez, A.T. (2002) Lignin attack during eucalypt wood decay by selected basidiomycetes: a Py-GC/MS study. J Anal Appl Pyrolysis 64: 421-431.

del Río, J.C., Rencoret, J., Marques, G., Gutiérrez, A., Ibarra, D., Santos, J.I., et al. (2008) Highly acylated (acetylated and/or $p$-coumaroylated) native lignins from diverse herbaceous plants. J Agric Food Chem 56: 9525-9534.

Ruiz-Dueñas, F.J., and Martínez, A.T. (2009) Microbial degradation of lignin: how a bulky recalcitrant polymer is efficiently recycled in nature and how we can take advantage of this. Microb Biotechnol 2: 164-177.

Schilling, J.S., Tewalt, J.P., and Duncan, S.M. (2009) Synergy between pretreatment lignocellulose modifications and saccharification efficiency in two brown rot fungal systems. Appl Microbiol Biotechnol 84: 465-475.

Srebotnik, E., and Messner, K. (1994) A simple method that uses differential staining and light microscopy to assess the selectivity of wood delignification by white rot fungi. Appl Environ Microbiol 60: 1383-1386.

Sun, Q.N., Qin, T.F., and Li, G.Y. (2009) Chemical groups and structural characterization of brown-rotted Pinus massoniana lignin. Int J Polym Anal Charact 14: 19-33.

Suzuki, M.R., Hunt, C.G., Houtman, C.J., Dalebroux, Z.D., and Hammel, K.E. (2006) Fungal hydroquinones contribute to brown rot of wood. Environ Microbiol 8: 2214-2223.

Vanden Wymelenberg, A., Gaskell, J., Mozuch, M., Sabat, G., Ralph, J., Skyba, O., et al. (2010) Comparative transcriptome and secretome analysis of wood decay fungi Postia placenta and Phanerochaete chrysosporium. Appl Environ Microbiol 76: 3599-3610.

Watanabe, T. (2007) Trends in biorefinery and pretreatments of lignocellulosics by white rot fungi. Mokuzai Gakkaishi 53: 1-13.

Yelle, D.J., Ralph, J., and Frihart, C.R. (2008a) Characterization of nonderivatized plant cell walls using high-resolution solution-state NMR spectroscopy. Magn Reson Chem 46: 508-517.

Yelle, D.J., Ralph, J., Lu, F., and Hammel, K.E. (2008b) Evidence for cleavage of lignin by a brown rot basidiomycete. Environ Microbiol 10: 1844-1849.

Zhang, L.M., and Gellerstedt, G. (2007) Quantitative 2D HSQC NMR determination of polymer structures by selecting suitable internal standard references. Magn Reson Chem 45: 37-45.

Zhang, L.M., Gellerstedt, G., Ralph, J., and Lu, F.C. (2006) NMR studies on the occurrence of spirodienone structures in lignins. J Wood Chem Technol 26: 65-79.

\section{Supporting information}

Additional Supporting Information may be found in the online version of this article:

Fig. S1. Macroscopic (top) and microscopic (bottom) aspects of wood (E. cordifolia) after white rot (left) and brown rot (right) under environmental conditions in the Austral rain- 
forest (Chiloe island, Chile). Wood after the selective and extensive removal of lignin (by $G$. australe) showed a soft fibrous texture and white colour being consumed by cattle as a natural feed (a); while the same wood after brown-rot decay (by an unidentified basidiomycete) exhibited a cubic appearance and reddish-brown colour (b). Light microscopy revealed selective lignin staining with safranin (d) while cellulose was stained with the Astra blue contrast dye (c). The bars (in c and d) correspond to $250 \mu \mathrm{m}$.

Fig. S2. Py-GC/MS of: (a) sound E. cordifolia wood; and (b) E. cordifolia wood degraded by a brown-rot fungus. The numbers refer to the lignin-derived compounds listed in Table S1. Letters refer to the polysaccharide-derived compounds: a, 2-methylfuran; b, hydroxyacetaldehyde; c, (3H)-furan-2-one; d, (2H)-furan-3-one; e, furfural; f, 2-hydroxymethylfuran; g, 2-acetylfuran; h, 2-methyl-2cyclopenten-1-one; i, (5H)-furan-2-one; j, 2,3-dihydro-5methylfuran-2-one; k, 5-methylfurfural; I, 4-hydroxy-5,6dihydro-(2H)-pyran-2-one; $m, \quad 2$-hydroxy-3-methyl-2cyclopenten-1-one; n, 3-hydroxy-2-methyl-(4H)-pyran-4-one; o, 3,5-dihydroxy-2-methyl-(4H)-pyran-4-one; hydroxymethyl-2-furfural; and q, levoglucosane.
Fig. S3. Py/TBAH of: (a) sound E. cordifolia wood; and (b) $E$. cordifolia wood degraded by a brown-rot fungus. The labels refer to the H-, G-, S- and MC-type lignin-derived compounds listed in Table S2, whose structures are depicted in Fig. S4. Fig. S4. Structures of the $p$-hydroxyphenyl $(H)$, guaiacyl $(G)$, syringyl (S) and methoxycatechol (MC) lignin-derived compounds released after $\mathrm{Py} / \mathrm{TBAH}$ of the sound and brownrotted E. cordifolia wood (Fig. S3)

Table S1. Relative molar areas (\%) of the compounds identified in the Py-GC/MS of the sound and brown-rotted $E$. cordifolia wood (Fig. S1).

Table S2. Relative molar areas (\%) of the p-hydroxyphenyl $(H)$, guaiacyl (G), syringyl (S) and methoxycatechol (MC) type lignin-derived compounds identified after $\mathrm{Py} / \mathrm{TBAH}$ of sound and brown-rotted E. cordifolia wood (Fig. S2).

Please note: Wiley-Blackwell are not responsible for the content or functionality of any supporting materials supplied by the authors. Any queries (other than missing material) should be directed to the corresponding author for the article. 


\author{
Selective lignin and polysaccharide removal in natural fungal decay of wood \\ as evidenced by in situ structural analyses \\ Angel T. Martínez ${ }^{1, *}$, Jorge Rencoret ${ }^{2, \dagger}$, Lidia Issue \\ Nieto ${ }^{1}$, Jesús Jiménez-Barbero ${ }^{1}$, Ana \\ Gutiérrez², José C. del Río ${ }^{2 *}$ \\ Article first published online: 1 AUG 2010 \\ DOI: 10.1111/j.1462-2920.2010.02312.x \\ (c) 2010 Society for Applied Microbiology and \\ Blackwell Publishing Ltd \\ Additional Information (Show All) \\ How to Cite Author Information Publication History

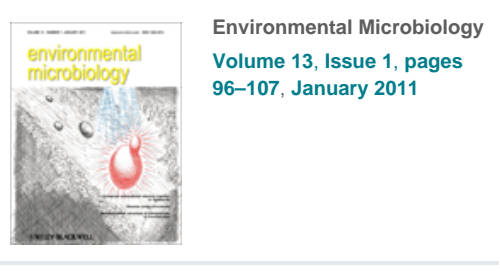 \\ Abstract Article References Supporting Information Cited By
}

View Full Article with Supporting Information (HTML) ～～Get PDF (933K) | Servicio de Enlaces CSIC

Fig. S1. Macroscopic (top) and microscopic (bottom) aspects of wood (E. cordifolia) after white rot (left) and brown rot (right) under environmental conditions in the Austral rainforest (Chiloe island, Chile). Wood after the selective and extensive removal of lignin (by G. australe) showed a soft fibrous texture and white colour being consumed by cattle as a natural feed (a); while the same wood after brown-rot decay (by an unidentified basidiomycete) exhibited a cubic appearance and reddish-brown colour (b). Light microscopy revealed selective lignin staining with safranin (d) while cellulose was stained with the Astra blue contrast dye (c). The bars (in c and d) correspond to $250 \mu \mathrm{m}$.

Fig. S2. Py-GC/MS of: (a) sound E. cordifolia wood; and (b) E. cordifolia wood degraded by a brown-rot fungus. The numbers refer to the lignin-derived compounds listed in Table S1. Letters refer to the polysaccharide-derived compounds: a, 2-methylfuran; b, hydroxyacetaldehyde; c, $(3 H)$-furan-2-one; $d,(2 H)$-furan-3-one; e, furfural; f, 2-hydroxymethylfuran; g, 2-acetylfuran; h, 2-methyl-2-cyclopenten-1-one; i, (5H)-furan-2-one; j, 2,3-dihydro-5-methylfuran-2-one; k, 5-methylfurfural; I, 4-hydroxy-5,6-dihydro-(2H)-pyran-2-one; m, 2hydroxy-3-methyl-2-cyclopenten-1-one; n, 3-hydroxy-2-methyl-(4H)-pyran-4-one; o, 3,5-dihydroxy-2-methyl-(4H)-pyran-4-one; p, 5-hydroxymethyl-2-furfural; and q, levoglucosane.

Fig. S3. Py/TBAH of: (a) sound E. cordifolia wood; and (b) E. cordifolia wood degraded by a brown-rot fungus. The labels refer to the H-, G-, S- and MC-type lignin-derived compounds listed in Table S2, whose structures are depicted in Fig. S4.

Fig. S4. Structures of the p-hydroxyphenyl $(\mathrm{H})$, guaiacyl $(\mathrm{G})$, syringyl $(\mathrm{S})$ and methoxycatechol $(\mathrm{MC})$ lignin-derived compounds released after Py/TBAH of the sound and brownrotted E. cordifolia wood (Fig. S3).

Table S1. Relative molar areas (\%) of the compounds identified in the Py-GC/MS of the sound and brown-rotted E. cordifolia wood (Fig. S1).

Table S2. Relative molar areas (\%) of the $p$-hydroxyphenyl (H), guaiacyl (G), syringyl (S) and methoxycatechol (MC) type lignin-derived compounds identified after Py/TBAH of sound and brown-rotted E. cordifolia wood (Fig. S2)

Please note: Wiley-Blackwell are not responsible for the content or functionality of any supporting materials supplied by the authors. Any queries (other than missing material) should be directed to the corresponding author for the article.

\begin{tabular}{|c|c|c|c|}
\hline Filename & Format & Size & Description \\
\hline EMI_2312_sm_fS1.eps & & $4240 \mathrm{~K}$ & Supporting info item \\
\hline EMI_2312_sm_fS2.eps & & $652 \mathrm{~K}$ & Supporting info item \\
\hline EMI_2312_sm_fS3.eps & & $378 \mathrm{~K}$ & Supporting info item \\
\hline EMI_2312_sm_fS4.eps & & $112 \mathrm{~K}$ & Supporting info item \\
\hline EMI $2312 \mathrm{sm}$ tS1-2.doc & & $140 \mathrm{~K}$ & Supporting info item \\
\hline
\end{tabular}

Please note: Wiley-Blackwell are not responsible for the content or functionality of any supporting materials supplied by the authors. Any queries (other than missing material) should be directed to the corresponding author for the article.

View Full Article with Supporting Information (HTML)

Get PDF (933K) | Servicio de Enlaces CSIC

More content like this

Find more content: like this article

Find more content written by: Angel T. Martínez | Jorge Rencoret | Lidia Nieto | Jesús Jiménez-Barbero | Ana Gutiérrez | José C. del Río | All Authors 

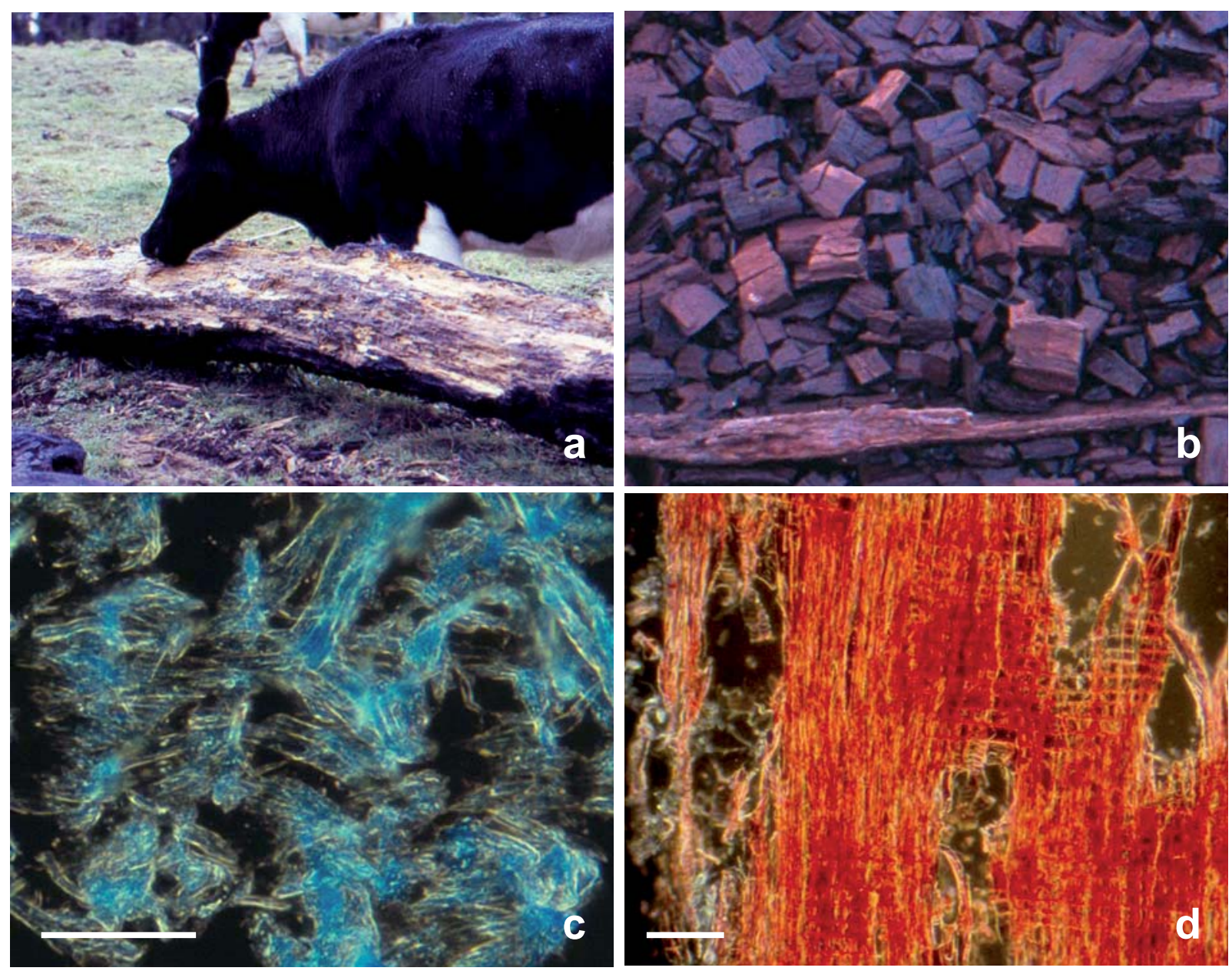

Fig S1 

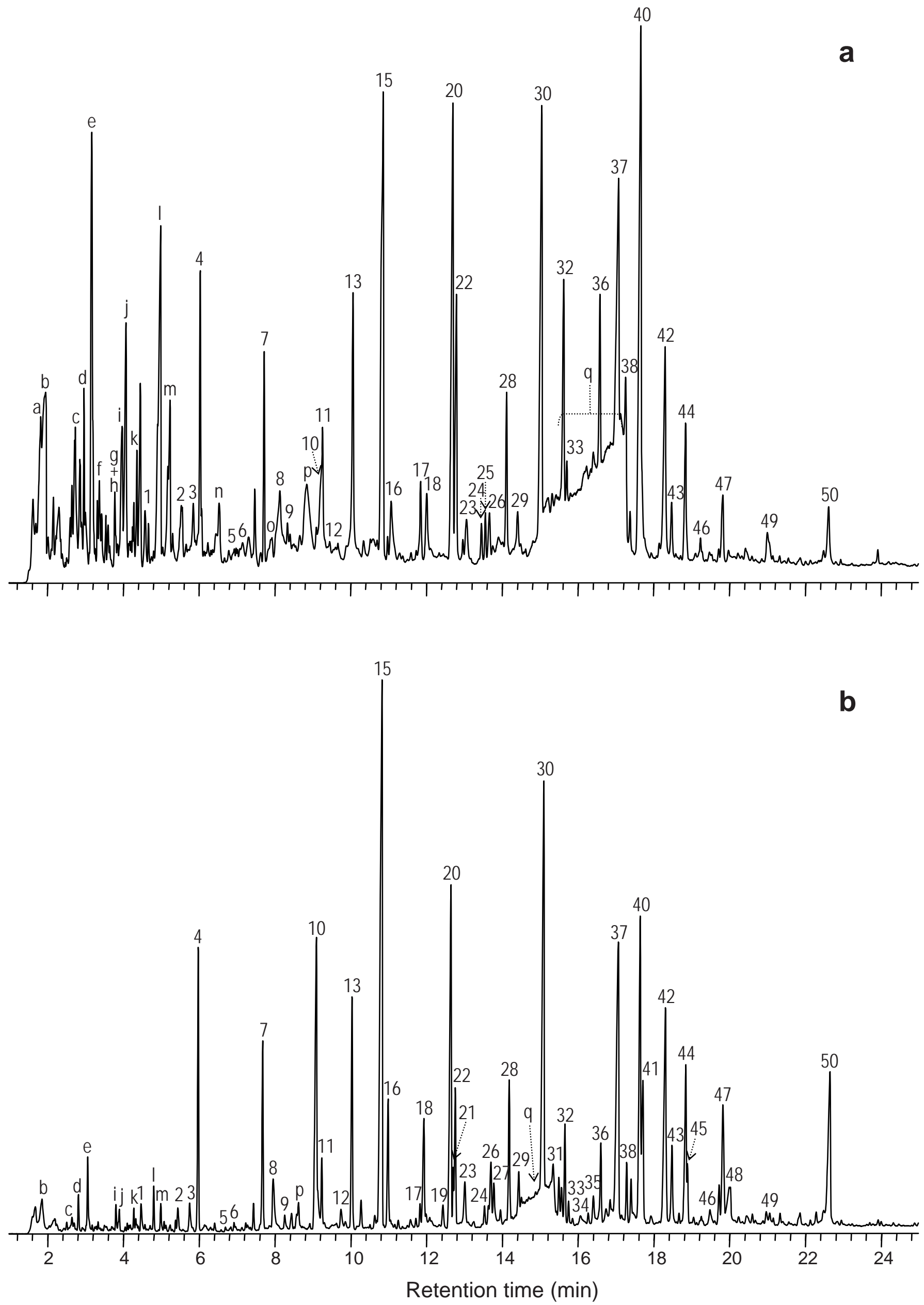

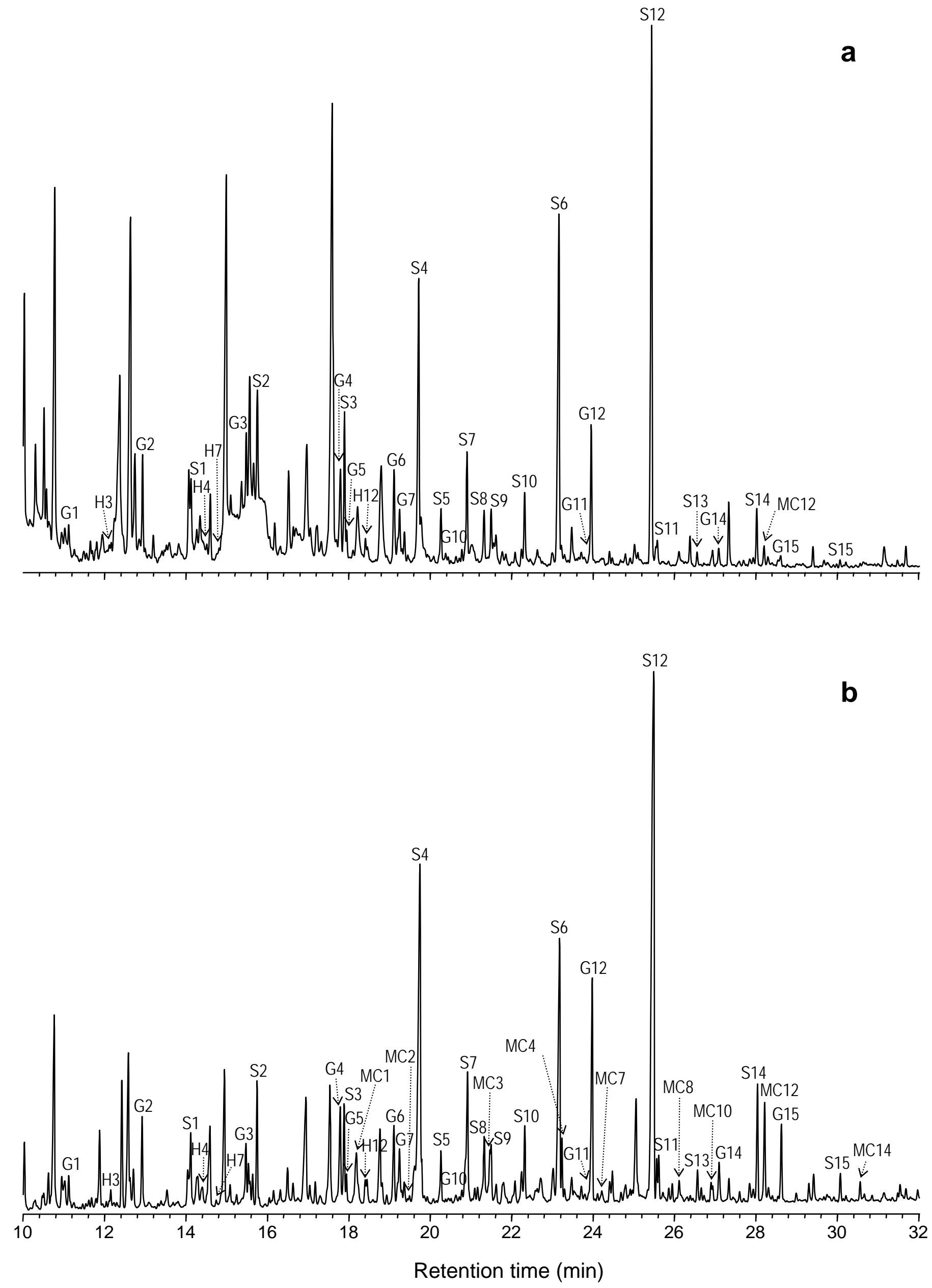
<smiles>[R]c1cccc(OC)c1OCCC</smiles>

G1 $\quad \mathrm{R}=\mathrm{H}$ S1 $\mathrm{R}=\mathrm{OMe}$ MC1 $\mathrm{R}=\mathrm{OBu}$<smiles>[R]c1cc(/C=C/C)cc(OC)c1OCCC</smiles>

$\begin{array}{ll}\text { G5 } & R=H \\ \text { S5 } & R=O M e\end{array}$<smiles>[R]c1cc(C(=O)OC)cc(OC)c1OCC</smiles>

S9<smiles>[R]c1cc(C)cc(OC)c1OCC</smiles>

$\begin{array}{ll}\text { G2 } & R=H \\ \text { S2 } & R=O M e \\ \text { MC2 } & R=O B u\end{array}$<smiles>[R]c1cc(C(=O)OCCC)cc(OC)c1O</smiles>

G6 $\quad \mathrm{R}=\mathrm{H}$ S6 $\mathrm{R}=\mathrm{OMe}$<smiles>[R]c1cc(C=C)cc([R])c1OCC</smiles><smiles>[R]c1cc(C=O)cc([R])c1OCC</smiles>

H3 $\quad \mathrm{R}_{1}=\mathrm{H}, \mathrm{R}_{2}=\mathrm{H}$

G3 $\mathrm{R}_{1}=\mathrm{H}, \mathrm{R}_{2}=\mathrm{OMe} \quad \mathbf{G} 4 \quad \mathrm{R}_{1}=\mathrm{H}, \mathrm{R}_{2}=\mathrm{OMe}$ S3 $\mathrm{R}_{1}=\mathrm{OMe}, \mathrm{R}_{2}=\mathrm{OMeS4} \quad \mathrm{R}_{1}=\mathrm{OMe}, \mathrm{R}_{2}=\mathrm{OMe}$ MC3 $R_{1}=\mathrm{OBu}, \mathrm{R}_{2}^{2}=\mathrm{OMeMC4} \quad \mathrm{R}_{1}=\mathrm{OBu}, \mathrm{R}_{2}^{2}=\mathrm{OMe}$<smiles>[R]c1cc(C(C)=O)cc([R])c1OCC</smiles>

H7 $\mathrm{R}_{1}=\mathrm{H}, \mathrm{R}_{2}=\mathrm{H}$<smiles>[R]c1cc(CC(C)=O)cc(OC)c1OCCC</smiles>

G7 $\quad \mathrm{R}_{1}=\mathrm{H}, \mathrm{R}_{2}=\mathrm{OMe}$

S7 $\quad \mathrm{R}_{1}=\mathrm{OMe}, \mathrm{R}_{2}=\mathrm{OMe}$ S8 $\quad \mathrm{R}=\mathrm{OMe}$ MC7 $R_{1}^{1}=O B u, R_{2}=O M e$ MC8 $R=O B u$<smiles>[R]c1cc(CCCOCCC)cc(OC)c1OCCC</smiles><smiles>[R]c1cc(C(=O)OCC)cc([R])c1OCCC</smiles><smiles>[R]c1cc(C(=O)CC)cc(OC)c1OCCC</smiles>

G10 R= H

S10 $\mathrm{R}=\mathrm{OMe}$
G11 $\mathrm{R}=\mathrm{H}$

S11 $\quad \mathrm{R}=\mathrm{OMe}$
$H 12 \quad \mathrm{R}_{1}=\mathrm{H}, \mathrm{R}_{2}=\mathrm{H}$

G12 $\mathrm{R}_{1}=\mathrm{H}, \mathrm{R}_{2}=\mathrm{OMe}$ S12 $R_{1}=O M e, R_{2}=O M e$ MC12 $R_{1}=\mathrm{OBu}, \mathrm{R}_{2}=\mathrm{OMe}$<smiles>[R]c1cc(COCCC)cc(OC)c1OCCC</smiles><smiles>[R]c1cc(CCC(=O)OCCC)cc(OC)c1OCCC</smiles>

G14

$\mathrm{R}=\mathrm{H}$

S14 $\quad \mathrm{R}=\mathrm{OMe}$<smiles>[R]c1cc(C(=O)/C=C/OCCC)cc(OC)c1OCCC</smiles>

G15 $\quad \mathrm{R}=\mathrm{H}$

S15 $\mathrm{R}=\mathrm{OMe}$ 
1 Table S1. Relative molar areas (\%) of the compounds identified in the Py-GC/MS of the 2 sound and brown-rotted E. cordifolia wood (Fig. S1).

\begin{tabular}{|c|c|c|c|}
\hline Label & compound & Sound wood & Brown-rotted wood \\
\hline 1 & Phenol & 0.7 & 0.7 \\
\hline 2 & Methylphenol & 0.6 & 0.6 \\
\hline 3 & Methylphenol & 0.7 & 0.7 \\
\hline 4 & Guaiacol & 3.9 & 4.7 \\
\hline 5 & Ethylphenol & 0.1 & 0.1 \\
\hline 6 & Ethylphenol & 0.2 & 0.1 \\
\hline 7 & 4-Methylguaiacol & 3.0 & 2.8 \\
\hline 8 & Catechol & 0.7 & 1.9 \\
\hline 9 & 4-Vinylphenol & 0.3 & 0.3 \\
\hline 10 & 3-Methoxycatechol & 2.3 & 7.4 \\
\hline 11 & 4-Ethylguaiacol & 1.2 & 0.9 \\
\hline 12 & Methylcatechol & 0.3 & 0.5 \\
\hline 13 & 4-Vinylguaiacol & 3.7 & 3.8 \\
\hline 14 & Eugenol & 1.3 & 0.3 \\
\hline 15 & Syringol & 12.9 & 14.4 \\
\hline 16 & 5-Methyl-3-methoxycatechol & 0.5 & 2.1 \\
\hline 17 & cis-Eugenol & 1.1 & 0.3 \\
\hline 18 & Vanillin & 1.5 & 1.9 \\
\hline 19 & 3,4-Dimethoxycatechol & 0.0 & 0.4 \\
\hline 20 & 4-Methylsyringol & 9.9 & 6.4 \\
\hline 21 & 5-Ethyl-3-methoxycatechol & 0.2 & 0.5 \\
\hline 22 & trans-Isoeugenol & 4.5 & 1.8 \\
\hline 23 & Homovanillin & 0.9 & 0.9 \\
\hline 24 & Propineguaiacol & 0.6 & 0.3 \\
\hline 25 & Propineguaiacol & 0.6 & 0.2 \\
\hline 26 & Acetoguaiacone & 0.9 & 0.9 \\
\hline 27 & 5-Vinyl-3-methoxycatechol & 0.1 & 0.6 \\
\hline 28 & 4-Ethylsyringol & 2.2 & 1.8 \\
\hline 29 & Guaiacyl acetone & 0.7 & 0.6 \\
\hline 30 & 4-Vinylsyringol & 8.6 & 8.0 \\
\hline 31 & Vanillic acid & 0.0 & 0.4 \\
\hline 32 & 4-Allylsyringol & 3.2 & 1.1 \\
\hline 33 & 4-Propylsyringol & 0.4 & 0.2 \\
\hline 34 & 5-Formyl-3-methoxycatechol & 0.0 & 0.3 \\
\hline 35 & 5-trans-Propenyl-3-methoxycatechol & 0.1 & 0.5 \\
\hline 36 & cis-4-Propenylsyringol & 2.2 & 1.0 \\
\hline 37 & Syringaldehyde & 6.4 & 6.9 \\
\hline 38 & Propinesyringol & 0.6 & 0.7 \\
\hline 39 & Propinesyringol & 0.5 & 0.5 \\
\hline 40 & trans-4-Propenylsyringol & 11.1 & 4.9 \\
\hline 41 & Homosyringaldehyde & 1.0 & 2.2 \\
\hline 42 & Acetosyringone & 4.0 & 4.5 \\
\hline 43 & Coniferylaldehyde & 0.9 & 1.3 \\
\hline 44 & Syringylacetone & 2.1 & 2.4 \\
\hline 45 & Syringic acid methyl ester & 0.0 & 0.5 \\
\hline 46 & cis-Sinapaldehyde & 0.2 & 0.2 \\
\hline 47 & Propiosyringone & 1.1 & 1.9 \\
\hline 48 & Syringic acid & 0.0 & 1.2 \\
\hline 49 & Dihydrosinapyl alcohol & 0.7 & 0.2 \\
\hline \multirow[t]{2}{*}{50} & trans-Sinapaldehyde & 1.1 & 3.0 \\
\hline & H:G:S:MC molar ratio & $2.7: 24.9: 68.4: 4.2$ & $2.5: 21.2: 62.1: 14.2$ \\
\hline
\end{tabular}




\begin{tabular}{|c|c|c|c|}
\hline Label & Compound & $\begin{array}{r}\text { Sound } \\
\text { wood }\end{array}$ & $\begin{array}{r}\text { Brown-rotted } \\
\text { wood }\end{array}$ \\
\hline $\mathrm{H} 3$ & 4-Butoxystyrene & 0.4 & 0.2 \\
\hline $\mathrm{H} 4$ & 4-Butoxybenzaldehyde & 0.7 & 0.9 \\
\hline $\mathrm{H} 7$ & 4-Butoxyacetophenone & 0.6 & 0.2 \\
\hline $\mathrm{H} 12$ & 4-Butoxybenzoic acid butyl ester & 0.7 & 0.7 \\
\hline G1 & 1-Butoxy-2-methoxybenzene & 1.4 & 1.0 \\
\hline G2 & 3-Methoxy-4-butoxytoluene & 3.9 & 3.0 \\
\hline G3 & 3-Methoxy-4-butoxystyrene & 2.9 & 1.7 \\
\hline G4 & 3-Methoxy-4-butoxybenzaldehyde & 3.1 & 3.4 \\
\hline G5 & 1-(3-Methoxy-4-butoxyphenyl)prop-2-ene & 0.8 & 0.5 \\
\hline G6 & 3-Methoxy-4-hydroxybenzoic acid butyl ester & 4.3 & 2.7 \\
\hline G7 & 3-Methoxy-4-butoxyacetophenone & 1.6 & 1.3 \\
\hline G8 & 3-Methoxy-4-butoxyphenylacetone & 0.0 & 0.0 \\
\hline G9 & 3-methoxy-4-butoxybenzoic acid methyl ester & 0.0 & 0.0 \\
\hline G10 & 1-(3-Methoxy-4-butoxyphenyl)propan-1-one & 0.4 & 0.2 \\
\hline G11 & 3-Methoxy-4-butoxybenzenepropanol butyl ether & 1.2 & 0.4 \\
\hline G12 & 3-Methoxy-4-butoxybenzoic acid butyl ester & 4.8 & 5.9 \\
\hline G13 & 3-Methoxy-4-butoxybenzenemethanol butyl ether & 0.0 & 0.0 \\
\hline G14 & 3-Methoxy-4-butoxybenzenepropanoic acid butyl ester & 0.6 & 1.0 \\
\hline G15 & 1-(3-Methoxy-4-butoxyphenyl)-3-butoxyprop-2-en-1-one (t) & 0.3 & 1.7 \\
\hline S1 & 1-Butoxy-2,6-dimethoxybenzene & 3.1 & 2.6 \\
\hline S2 & 3,5-Dimethoxy-4-butoxytoluene & 4.4 & 3.3 \\
\hline S3 & 3,5-Dimethoxy-4-butoxystyrene & 4.7 & 2.4 \\
\hline S4 & 3,5-Dimethoxy-4-butoxybenzaldehyde & 12.4 & 15.4 \\
\hline S5 & 1-(3,5-Dimethoxy-4-butoxyphenyl)prop-2-ene & 1.8 & 1.2 \\
\hline S6 & 3,5-Dimethoxy-4-hydroxybenzoic acid butyl ester & 15.8 & 9.6 \\
\hline S7 & 3,5-Dimethoxy-4-butoxyacetophenone & 3.6 & 4.2 \\
\hline S8 & 3,5-Dimethoxy-4-butoxyphenylacetone & 1.7 & 1.5 \\
\hline S9 & 3,5-Dimethoxy-4-butoxybenzoic acid methyl ester & 1.6 & 1.0 \\
\hline S10 & 1-(3,5-Dimethoxy-4-butoxyphenyl)propan-1-one & 2.3 & 1.7 \\
\hline S11 & 3,5-Dimethoxy-4-butoxybenzenepropanol butyl ether & 0.6 & 0.7 \\
\hline S12 & 3,5-Dimethoxy-4-butoxybenzoic acid butyl ester & 17.6 & 22.0 \\
\hline S13 & 3,5-Dimethoxy-4-butoxybenzenemethanol butyl ether & 0.4 & 0.7 \\
\hline S14 & 3,5-Dimethoxy-4-butoxybenzenepropanoic acid butyl ester & 1.5 & 2.3 \\
\hline S15 & 1-(3,5-Dimethoxy-4-butoxyphenyl)-3-butoxyprop-2-en-1-one & 0.2 & 0.6 \\
\hline MC1 & 1,2-Dibutoxy-3-methoxybenzene & 0.0 & 0.5 \\
\hline MC2 & 3,4-Dibutoxy-5-methoxytoluene & 0.0 & 0.1 \\
\hline MC3 & 3,4-Dibutoxy-5-methoxystyrene & 0.0 & 0.2 \\
\hline MC4 & 3,4-Dibutoxy-5-methoxybenzaldehyde & 0.0 & 1.1 \\
\hline MC7 & 3,4-Dibutoxy-5-methoxyacetophenone & 0.0 & 0.4 \\
\hline MC8 & 3,4-Dibutoxy-5-methoxyphenylacetone & 0.0 & 0.5 \\
\hline MC10 & 1-(3,4-Dibutoxy-5-methoxyphenyl)-propan-1-one & 0.0 & 0.5 \\
\hline MC12 & 3,4-Dibutoxy-5-methoxybenzoic acid butyl ester & 0.5 & 2.0 \\
\hline \multirow[t]{2}{*}{ MC14 } & 3,4-Dibutoxy-5-methoxybenzenepropanoic acid butyl ester & 0.0 & 0.3 \\
\hline & $\mathrm{H}: \mathrm{G}: \mathrm{S}: \mathrm{MC}$ molar ratio & 2.4:25.2:71.9:0.5 & $2.1: 23.0: 69.4: 5.6$ \\
\hline
\end{tabular}

Table S2. Relative molar areas (\%) of the $p$-hydroxyphenyl (H), guaiacyl (G), syringyl (S) and methoxycatechol (MC) type lignin-derived compounds identified after Py/TBAH of sound and brown-rotted E. cordifolia wood (Fig. S2).

(t) tentatively assigned. 